\title{
WATER HARVESTING - PAST AND FUTURE
}

\author{
DIETER PRINZ \\ Universität Karlsruhe (TH) \\ Institut für Wasserbau und Kulturtechnik \\ 76128 Karlsruhe
}

\begin{abstract}
Water harvesting, defined as the collection of runoff and its use for the irrigation of crops, pastures and trees, and for livestock consumption, comprises six different forms, primarily defined by the ratio between collecting and receiving area: (1) Roof Top Water Harvesting, (2) Water Harvesting for Animal Consumption, (3) Inter-Row Water Harvesting, (4) Microcatchment Water Harvesting, (5) Medium-sized Catchment Water Harvesting and (6) Large Catchment Water Harvesting. The common goal of all forms is to secure water supply for annual crops, pastures, trees and animals in dry areas without tapping groundwater or river-water sources. In the past, water harvesting was the backbone of agriculture in arid and semi-arid areas world-wide. After a decline, it gained new interest during past decades. Its future role will be as a linking element between rainfed agriculture, soil and water conservation and irrigated agriculture, still using untapped water resources in arid lands, alleviating slightly the stress on drought-ridden farmers and communities.
\end{abstract}

\section{Introduction}

As long as mankind has inhabited semi-arid areas and cultivated agricultural crops, it has practised some kind of water harvesting. Based on "natural water harvesting" the use of the waters of ephemeral streams was already the basis of livelihood in the arid and semi-arid areas many thousands of years ago, allowing the establishment of cities in the desert (Evenari et al. 1971).

Presumably millions of hectares of land in the dry parts of the world were once used for water harvesting but a variety of causes has brought about a steady decline.

The European expansion, especially the technological development since 1850, lead to a steady increase in area under "classical" irrigation techniques with preference to large schemes. Small-scale irrigation and traditional irrigation techniques received inadequate attention. The latter include the various techniques of water harvesting and supplementary irrigation.

During recent decades the interest in water harvesting has increased and national as well as international bodies have launched programmes to investigate the potential of water harvesting and to expand its area.

The sustainability of water harvesting systems was in the past based on the 'fitting together' of the basic needs of the farmers, the local natural conditions and the prevailing economic and political conditions of the region. The preconditions for a positive future development of water harvesting will be the very same (Prinz 1994).

\section{Basic Concepts and Characterization of Water Harvesting}

\subsection{GENERAL CONCEPT}

Water harvesting is applied in arid and semi-arid regions where rainfall is either not sufficient to sustain a good crop and pasture growth or where, due to the erratic nature of precipitation, the risk of crop failure is very high. Water harvesting can significantly increase plant production in drought prone areas by concentrating the rainfall/runoff in parts of the total area.

The intermittent character of rainfall and runoff and the ephemerality of floodwater flow requires some kind of storage. There might be some kind of interim storage in tanks, cisterns or reservoirs or soil itself serves as a reservoir for a certain period of time (Finkel and Finkel 1986).

Water harvesting is based on the utilisation of surface runoff; therefore it requires runoff producing and runoff receiving areas. In most cases, with the exception of floodwater harvesting from far away catchments, water harvesting utilizes the rainfall from the same location or region. I does not include its 
conveyance over long distances or its use after enriching the groundwater reservoir. Water harvesting projects are generally local and small scale projects.

\subsection{DEFINITION, GOALS AND PARAMETERS}

There is no generally accepted definition of water harvesting (Reij et al. 1988). The definition used in this paper covers "the collection of runoff and its use for the irrigation of crops, pastures and trees, and for livestock consumption" (Finkel and Finkel 1986).

The goals of water harvesting are:

? Restoring the productivity of land which suffers from inadequate rainfall.

? Increasing yields of rainfed farming

? Minimizing the risk in drought prone areas

? Combating desertification by tree cultivation

? Supplying drinking water for animals.

In regions with an annual precipitation between 100 and $700 \mathrm{~mm}$, low cost water harvesting might provide an interesting alternative if irrigation water from other sources is not readily available or too costly. (In summer rainfall areas the minimum precipitation for water harvesting is around $200 \mathrm{~mm} /$ year). In areas with more than $600-700 \mathrm{~mm}$ annual rainfall water harvesting techniques can prolong the cropping season. In comparison with pumping water, water harvesting saves energy and maintenance costs. These advantages are countered by the problem of unreliability of rainfall, which can partly be overcome by interim storage (cisterns, small reservoirs etc.). Modern hydrological tools (e.g. calculation of rainfall probability and water yield) allow a more precise determination of the necessary size of the catchment area.

As mentioned before, the central elements of all water harvesting techniques are:

- a runoff area (catchment) with a sufficiently high run-off coefficient (impermeability would be optimal), and

- a "run-on" area, where the accumulated water is stored and/ or utilized. In most cases the runoff is used for agricultural crops, the water then being stored in the soil profile. A high storage capacity of the soil (i.e. medium textured soils) and a sufficient soil depth (> $1 \mathrm{~m})$ are prerequisites here (Huibers 1985). The water retention capacity has to be high enough to supply the crops with water until the next rainfall event.

The most important parameters to be taken into consideration in practising water harvesting are therefore: rainfall distribution, rainfall intensity, runoff characteristics of the catchment, water storage capacity of soils, cisterns or reservoirs, the agricultural crops, available technologies and socio-economic conditions (Tauer and Prinz 1992).

The tools used to identify possible runoff irrigation areas are:

- field visits;

- areal surveys and evaluation of aerial photographs;

- satellite images and their classification and evaluation (Tauer and Humborg 1992).

\section{Commonly Applied Forms}

As mentioned before, water harvesting has been practised for millennia and is still applied world-wide. Of the great number of forms in existence with various names, six forms are generally recognized:

a) roof top water harvesting

b) water harvesting for animal consumption

c) inter-row water harvesting

d) microcatchment water harvesting

e) medium-sized catchment water harvesting

f) large catchment water harvesting.

Table 1 gives an overview of these forms and their most prominent features. Fig. 1 shows the annual precipitation ranges for various water harvesting $(\mathrm{WH})$ forms. 


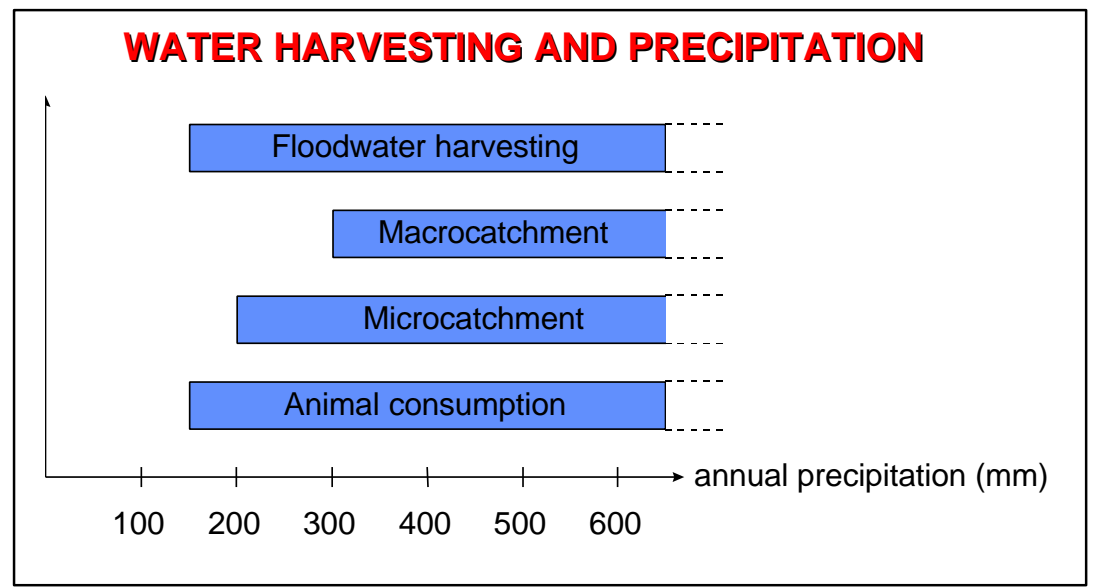

Fig. 1. Annual precipitation ranges for different forms of water harvesting in summer rainfall areas

\section{a) Roof top water harvesting}

Rain "harvested" from the roofs of buildings including greenhouses is, in many locations, a very valuable resource being used mainly for drinking and domestic purposes (UNEP 1983). However, for the purpose of this paper, roof top harvesting is excluded as its use for agricultural purposes is limited to very few locations only (Papadopoulos 1994).

b) Water harvesting for animal consumption

Ancient dwellers harvested rain water for human and animal consumption by redirecting the water running down hillslopes into cisterns.

Presently, this tradition is still practised in many regions, but where the means are available, surfaces used for rainwater collection are usually either physically compacted,

chemically treated or covered to increase runoff volume:

(i) Clay soils are well suited for compaction. The surfaces are shaped, smoothened and then compacted e.g. by tractor and rubber-tired rollers.

(ii) Sodium salts, wax, latexes, asphalt, bitumen, fiberglas and silicones can be used as sealants on soils which do not swell with moisture (Frasier 1994). Plots treated with sun-melted granulated paraffin-wax yielded about 90 percent of the rainfall as runoff, compared to 30 percent from untreated plots.

(iii) Concrete, plastic sheeting, butyl rubber and metal foil can also be used to cover the soil for rainwater harvesting. Gravel may protect the underlying membrane against radiation and wind damage.

The runoff water is collected in lined or unlined pits down the slope of the catchment area (Fig. 2), (Frasier and Myers 1983, Dutt et al. 1981).

Fig. 2. Western Australia rainwaterharvesting system for animal consumption. The runoff-surface is compacted and treated. (Source: FAO 1977, redrawn)

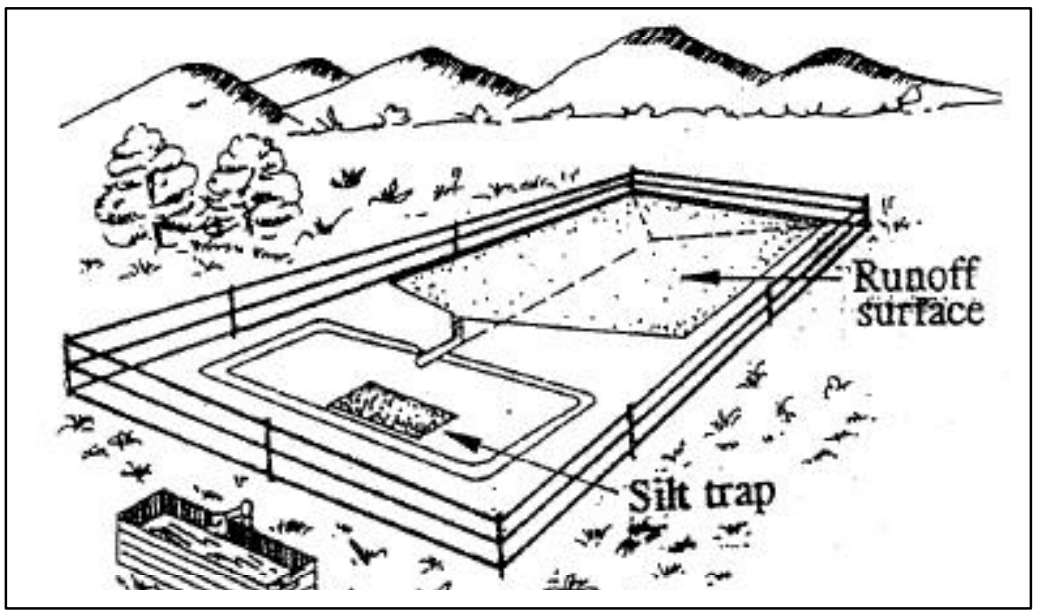




\section{c). Inter-row water harvesting}

Inter-row water harvesting is applied either on flat land or on gentle slopes of up to $5 \%$ having soil at least $1 \mathrm{~m}$ deep. The annual rainfall should not be less than $200 \mathrm{~mm} / \mathrm{year}$.

On flat terrain ( 0 - $1 \%$ inclination) bunds are constructed, compacted and, under higher-input conditions, treated with chemicals to increase runoff. The aridity of the location determines the catchment to cropping ratio (CCR), which varies from 1:1 to 5:1 (Fig. 3). Examples are given from India (Vijayalakshmi et al. 1982) and the USA (Frasier 1994).

A

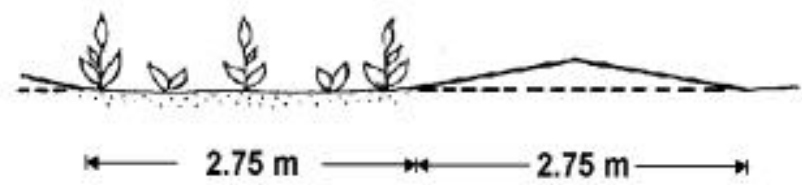

B

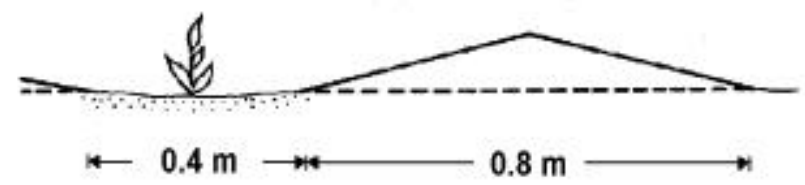

C

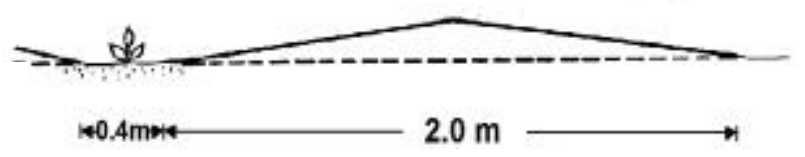

Fig. 3. Various forms of flat-land inter-row water harvesting; from A - C increasing CCR/aridity of location.

(Source: Prinz 1986)

On sloping land (1 - 20\% inclination) these systems are called "contour ridges" (USA) or "Matuta" (East Africa). The ridges of about $0.40 \mathrm{~m}$ height are built 2 to $20 \mathrm{~m}$ apart, depending on slope, soil surface treatment, general CCR and type of crop to be grown. The catchment area should be weeded and compacted; the crops are either grown in the furrow, along the upper side of the bund or on top of the bund. On sloping land, this system is recommended only for areas with a known regular rainfall pattern; very high rainfall intensities may cause breakages of the bunds. Crops cultivated in row water harvesting systems are maize, beans, millet, rice or (in the USA) grapes and olives (Pacey and Cullis 1986, Finkel and Finkel 1986, Tobby 1994).

The preparation of the land for inter-row water harvesting can be fully mechanized.

\section{d) Microcatchment systems}

Microcatchment water harvesting (MC-WH) is a method of collecting surface runoff from a small catchment area and storing it in the root zone of an adjacent infiltration basin. This infiltration basin may be planted with a single tree, bush or with annual crops (Boers and Ben-Asher 1982).

Fig. 4 depicts various microcatchment systems in use.

The advantages of MC-WH systems are:

? Simple design and cheap to install, therefore easily replicable and adaptable.

? Higher runoff efficiency than medium or large scale water harvesting systems; no conveyance losses.

? Erosion control function

? Can be constructed on almost any slope, including almost level plains. 


\begin{tabular}{|c|c|c|c|}
\hline Type & Illustration & Parameters & $\begin{array}{l}\text { Remarks \& } \\
\text { References }\end{array}$ \\
\hline Negarin & & $\begin{array}{l}\mathrm{CA}=3-250 \\
\mathrm{CR}=1-10 \\
\mathrm{CCR}=3: 1-25: 1 \\
\mathrm{PREC}=150-600 \mathrm{~mm} / \mathrm{a} \\
\mathrm{SL}=1-20 \%\end{array}$ & $\begin{array}{l}\text { Ben-Asher } \\
1988\end{array}$ \\
\hline Pitting & 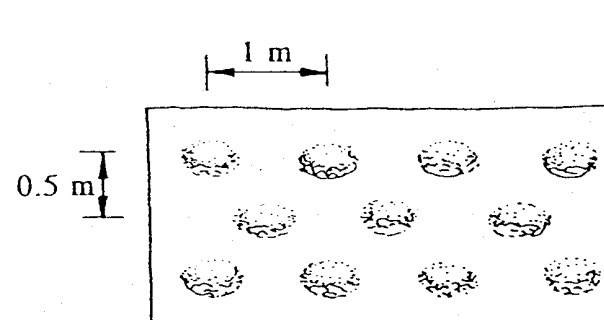 & $\begin{array}{l}\mathrm{CA}=0.25 \\
\mathrm{CR}=0.08 \\
\mathrm{CCR}=3: 1 \\
\mathrm{PREC}=350-600 \mathrm{~mm} / \mathrm{a} \\
\mathrm{SL}=0-5 \%\end{array}$ & $\begin{array}{l}\text { "Zay system" } \\
\text { (West Africa), } \\
\text { "Kitui Pitting", } \\
\text { "Katumani Pit- } \\
\text { ting" (Kenya) } \\
\text { Buritz et al. } \\
1986 \\
\text { Gichangi et al. } \\
1989\end{array}$ \\
\hline $\begin{array}{l}\text { Contour } \\
\text { ridges }\end{array}$ & & $\begin{array}{l}\mathrm{CA}=100 \\
\mathrm{CR}=20 \\
\mathrm{CCR}=5: 1 \\
\mathrm{PREC}=300-600 \mathrm{~mm} / \mathrm{a} \\
\mathrm{SL}=5-25 \%\end{array}$ & Critchley 1987 \\
\hline $\begin{array}{l}\text { Semi-circular } \\
\text { hoops (demi- } \\
\text { lunes); } \\
\text { Triangular } \\
\text { bunds }\end{array}$ & & $\begin{aligned} \mathrm{CA} & =24-226 \\
\mathrm{CR} & =6-57 \\
\mathrm{CCR} & =4: 1 \\
\mathrm{PREC} & =300-600 \mathrm{~mm} / \mathrm{a} \\
\mathrm{SL} & =2-20 \%\end{aligned}$ & MoALD 1984 \\
\hline
\end{tabular}

Fig. 4a. Various types of microcatchment (MC) water harvesting $\mathrm{CA}=$ Catchment size $\left(\mathrm{m}^{2}\right)$ PREC $=$ Precipitation $\mathrm{CR}=$ Cropping area $\left(\mathrm{m}^{2}\right)$ $\mathrm{SL}=$ Slope

$\mathrm{CCR}=$ Catchment: Cropping Ratio 
6

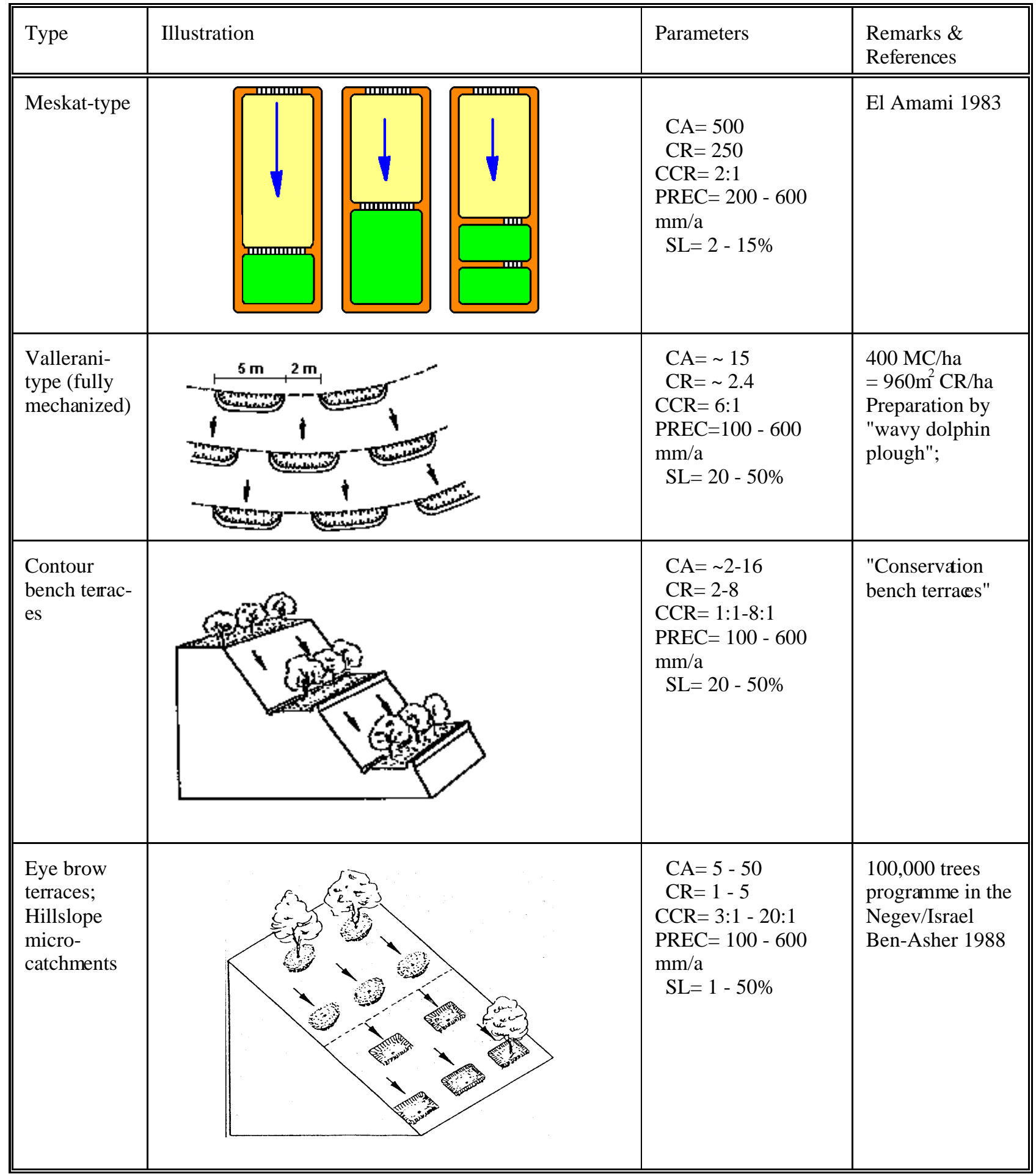

Fig. 4b. Various types of microcatchment (MC) water harvesting

$\mathrm{CA}=$ Catchment size $\left(\mathrm{m}^{2}\right)$

$\mathrm{CCR}=$ Catchment: Cropping Ratio
$\mathrm{CR}=$ Cropping area $\left(\mathrm{m}^{2}\right.$

$\mathrm{PREC}=$ Precipitation
$\mathrm{SL}=$ Slope 


\begin{tabular}{|c|c|c|c|}
\hline Type & Illustration & Parameters & $\begin{array}{l}\text { Remarks \& } \\
\text { References }\end{array}$ \\
\hline Stone dams & $5=$ & $\begin{array}{l}\text { (extreme varia- } \\
\text { tions) } \\
\mathrm{PREC}=300-600 \\
\mathrm{~mm} / \mathrm{a}\end{array}$ & $\begin{array}{l}\text { Diguettes or } \\
\text { Digues filtrantes: } \\
\text { Permeable con- } \\
\text { tour check dams }\end{array}$ \\
\hline $\begin{array}{l}\text { Large semi- } \\
\text { circular hoops }\end{array}$ & & $\begin{array}{l}\mathrm{CA}=750-10,000 \\
\mathrm{CR}=50-350 \\
\mathrm{CCR}=15: 1-40: 1 \\
\mathrm{PREC}=200- \\
400 \mathrm{~mm} / \mathrm{a} \\
\mathrm{SL}=1-10 \%\end{array}$ & $\begin{array}{l}\text { Staggered posi- } \\
\text { tion: used for } \\
\text { crops or pasture } \\
\text { improvement } \\
\text { Reij et al. } 1988\end{array}$ \\
\hline $\begin{array}{l}\text { Trapezoidal } \\
\text { bunds }\end{array}$ & 00 & $\begin{array}{l}\mathrm{CA}=5-3 \times 10^{5} \\
\mathrm{CR}=3,500 \\
\mathrm{CCR}=15: 1-100: 1 \\
\mathrm{PREC}=200-400 \\
\mathrm{~mm} / \mathrm{a} \\
\mathrm{SL}=1-10 \%\end{array}$ & $\begin{array}{l}\text { Staggered posi- } \\
\text { tion; mainly for } \\
\text { crops } \\
\text { Reij et al. } 1988\end{array}$ \\
\hline $\begin{array}{l}\text { Hillside con- } \\
\text { duit systems }\end{array}$ & $\Leftrightarrow$ & $\begin{array}{l}\mathrm{CA}=10-10^{7} \\
\mathrm{CR}=1-10^{5} \\
\mathrm{CCR}=10: 1-100: 1 \\
\mathrm{PREC}=100-600 \\
\mathrm{~mm} / \mathrm{a} \\
\mathrm{SLCA}=>10 \% \\
\mathrm{SLCR}=0-10 \%\end{array}$ & $\begin{array}{l}\text { Examples: Avdat } \\
\text { and Shifta Expe- } \\
\text { rimental Farms, } \\
\text { Negev, Israel; } \\
\text { For trees and } \\
\text { annual crops } \\
\text { Klemm } 1990\end{array}$ \\
\hline I iman tamman & & $\begin{array}{l}\mathrm{CA}=2 \times 10^{4}- \\
2 \times 10^{5} \\
\mathrm{CR}=1,000-5,000 \\
\mathrm{CCR}=20: 1-100: 1 \\
\mathrm{PREC}=100-300 \\
\mathrm{~mm} / \mathrm{a} \\
\mathrm{SL}=1-10 \%\end{array}$ & $\begin{array}{l}\text { In Israel mainly } \\
\text { planted to Euca- } \\
\text { lyptus tree spe- } \\
\text { cies; sometimes } \\
\text { built in succes- } \\
\text { sion. Bruins et al. } \\
1986\end{array}$ \\
\hline $\begin{array}{l}\text { Cultivated } \\
\text { reservoirs }\end{array}$ & 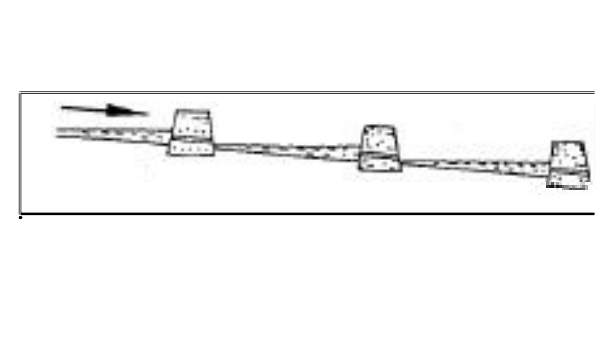 & $\begin{array}{l}\mathrm{CA}=1,000- \\
10,000 \\
\mathrm{CR}=100-2,000 \\
\mathrm{CCR}=10: 1-100: 1 \\
\mathrm{PREC}=150-600 \\
\mathrm{~mm} / \mathrm{a} \\
\mathrm{SLCA}=>10 \% \\
\mathrm{SLCR}=0-10 \%\end{array}$ & $\begin{array}{l}\text { Khadin, Rajastan } \\
\text { (India); Ahar, } \\
\text { Bihar (India); } \\
\text { Tera, SE Sudan } \\
\text { Kolarkar et al. } \\
\text { 1983, Pacey and } \\
\text { Cullis, } 1986\end{array}$ \\
\hline
\end{tabular}

Fig. 5. Types of medium-sized catchment water harvesting

$\mathrm{CA}=$ Catchment size $\left(\mathrm{m}^{2}\right)$

$\mathrm{CR}=$ Cropping area $\left(\mathrm{m}^{2}\right)$

PREC $=$ Precipitation

$\mathrm{SL}=$ Slope

$\mathrm{CCR}=$ Catchment: Cropping ratio

SLCA $=$ Slope of catchment area

$\mathrm{SLCR}=$ Slope of cropping area 
The disadvantages of MC-WH systems are:

? The catchment uses potentially arable land (exception: steep slopes)

? The catchment area has to be maintained, i.e. kept free of vegetation which requires a relatively high labour input.

? If overtopping takes place during exceptionally heavy rainstorms, the systems may be irrevocably damaged.

? Low crop density, low yield in comparison with other irrigation methods (e.g. 40 trees per hectare for the Negarin type WH, Fig. 4a).

\section{e) Medium-sized catchment water harvesting}

Water harvesting from medium-sized catchments $\left(1,000 \mathrm{~m}^{2}-200 \mathrm{ha}\right)$ is referred to by some authors as "water harvesting from long slopes", as "macro-catchment water harvesting" or as "harvesting from external catchment systems" (Pacey and Cullis 1988, Reij et al. 1988) It is characterized by:

? A CCR of 10:1 to 100:1; the catchment being located outside the arable areas.

? The predominance of turbulent runoff and channel flow of the catchment water in comparison with sheet or rill flow of microcatchments.

? The partial area contribution phenomenon which is not relevant for micro catchments.

? The catchment area may have an inclination of 5 to $50 \%$; the cropping area is either terraced or located in flat terrain.

Fig. 5 shows the most prominent types of this system.

\section{f) Large catchment water harvesting}

Large catchment water harvesting comprises systems with catchments being many square kilometres in size, from which runoff water flows through a major wadi (bed of an ephemeral stream), necessitating more complex structures of dams and distribution networks. Two types are mainly distinguished:

? Floodwater harvesting within the stream bed, and

? Floodwater diversion.

"Floodwater harvesting within the stream bed" means blocking the water flow to inundate the valley bottom of the entire flood plain, to force the water to infiltrate and use the wetted area for crop production or pasture improvement (Fig. 6).

"Floodwater diversion" means forcing the wadi water to leave its natural course and conveying it to nearby areas suitable for arable cropping. Floodwater diversion techniques were already applied several thousand years ago (e.g. Marib, North Yemen; Brunner and Haefner 1986) and systems are known from NW Mexico, Pakistan, Tunisia ("Jessour system"), Kenya, China etc. (Reij et al. 1988), (Fig. 7). The CCR ranges from 100:1 to 10,000: 1 .

\section{The Past Role of Water Harvesting}

\subsection{GENERAL ASPECTS}

As mentioned before, water harvesting played a more important role in the past for the well-being of people in dry areas than it currently does. The reasons are manyfold:

? Alternative sources of drinking water and water for irrigation were not available:

- no pumping from groundwater or other deep water sources

- very few large dams

- no long distance conveying of water through lined canals, pipes etc.

? The building of structures for water harvesting, the cleaning and smoothing of runoff surfaces, the maintenance of canals and reservoirs etc. are labour demanding: Labour was a cheap resource, or even unpaid as in the case of slaves. 
Table 1. Overview of the main types of water harvesting (WH)

\begin{tabular}{|c|c|c|c|c|c|c|}
\hline WH-type & $\begin{array}{l}\text { Kind of } \\
\text { flow }\end{array}$ & $\begin{array}{l}\text { Kind of } \\
\text { surface }\end{array}$ & $\begin{array}{l}\text { Size of } \\
\text { catch- } \\
\text { ment }\end{array}$ & $\begin{array}{l}\text { Catch- } \\
\text { ment: } \\
\text { cropping } \\
\text { area ratio }\end{array}$ & $\begin{array}{l}\text { Water } \\
\text { storage } \\
\text { type }\end{array}$ & Water use \\
\hline $\begin{array}{l}\text { Roof top } \\
\text { water } \\
\text { harvesting }\end{array}$ & \multirow{3}{*}{$\begin{array}{l}\text { Sheet } \\
\text { flow }\end{array}$} & $\begin{array}{l}\text { Roofs of } \\
\text { all kinds }\end{array}$ & small & & $\begin{array}{l}\text { Tanks, } \\
\text { jars, } \\
\text { cisterns }\end{array}$ & $\begin{array}{l}\text { Drinking, } \\
\text { domestic, } \\
\text { livestock }\end{array}$ \\
\hline $\begin{array}{l}\text { Water har- } \\
\text { vesting for } \\
\text { animal } \\
\text { consuption }\end{array}$ & & $\begin{array}{l}\text { Treated } \\
\text { ground } \\
\text { surfaces }\end{array}$ & $>3 \mathrm{ha}$ & $\begin{array}{l}\text { extreme } \\
\text { various }\end{array}$ & $\begin{array}{l}\text { Tanks, } \\
\text { cisterns }\end{array}$ & Livestock \\
\hline $\begin{array}{l}\text { Inter-row } \\
\mathrm{WH}\end{array}$ & & $\begin{array}{l}\text { Treated } \\
\text { ground } \\
\text { surfaces }\end{array}$ & $1-5 \mathrm{~m}^{2}$ & $1: 1-7: 1$ & $\begin{array}{l}\begin{array}{l}\text { Soil } \\
\text { profile }\end{array} \\
\text { (reser- } \\
\text { voirs, } \\
\text { cis- } \\
\text { terns) }\end{array}$ & \multirow[t]{4}{*}{$\begin{array}{l}\text { Tree, } \\
\text { bush, } \\
\text { vegetable } \\
\text { and field } \\
\text { crops }\end{array}$} \\
\hline $\begin{array}{l}\text { Micro- } \\
\text { catchment } \\
\text { WH }\end{array}$ & $\begin{array}{l}\text { Sheet } \\
\text { and rill } \\
\text { flow }\end{array}$ & $\begin{array}{l}\text { Treated } \\
\text { and un- } \\
\text { treated } \\
\text { ground } \\
\text { surfaces }\end{array}$ & $\begin{array}{l}2-1000 \\
\mathrm{~m}^{2}\end{array}$ & $1: 1-25: 1$ & $\begin{array}{l}\text { Soil } \\
\text { profile } \\
\text { (reser- } \\
\text { voirs, } \\
\text { cis- } \\
\text { terns) }\end{array}$ & \\
\hline $\begin{array}{l}\text { Medium- } \\
\text { sized } \\
\text { catchment } \\
\text { WH }\end{array}$ & $\begin{array}{l}\text { Turbu- } \\
\text { lent } \\
\text { runoff/ } \\
\text { channel } \\
\text { flow }\end{array}$ & $\begin{array}{l}\text { Treated } \\
\text { or un- } \\
\text { treated } \\
\text { ground } \\
\text { surfaces }\end{array}$ & $\begin{array}{l}1000 \mathrm{~m}^{2} \\
-200 \mathrm{ha}\end{array}$ & $\begin{array}{l}\text { 10:1 - } \\
100: 1\end{array}$ & $\begin{array}{l}\begin{array}{l}\text { Soil } \\
\text { profile }\end{array} \\
\text { (reser- } \\
\text { voirs, } \\
\text { cis- } \\
\text { terns) }\end{array}$ & \\
\hline $\begin{array}{l}\text { Large catch- } \\
\text { ment } \\
\text { WH }\end{array}$ & $\begin{array}{l}\text { Flood } \\
\text { water } \\
\text { flow }\end{array}$ & $\begin{array}{l}\text { Un- } \\
\text { treated } \\
\text { ground } \\
\text { surfaces }\end{array}$ & $\begin{array}{l}200 \mathrm{ha}- \\
50 \mathrm{~km}^{2}\end{array}$ & $\begin{array}{l}\text { 100:1 - } \\
\text { 10,000:1 }\end{array}$ & $\begin{array}{l}\text { Soil } \\
\text { profile }\end{array}$ & \\
\hline
\end{tabular}


Figure 6: Floodwater harvesting within the stream - bed: design of rock barrier's used to spread the water in large, shallow wadis (Nabataen system) source: Evenari and Koller 1956, from Cox and Atkins 1979

? Agriculture was the backbone of the society and very few other choices to generate income were given. Therefore, relatively more input was invested in agriculture including runoff agriculture.

Various examples shall be given to illustrate the past role of water harvesting worldwide. Unfortunately, the extreme importance of certain water harvesting techniques is often not reflected by the number or depth of publications.

Some of the techniques mentioned are still presently practised.

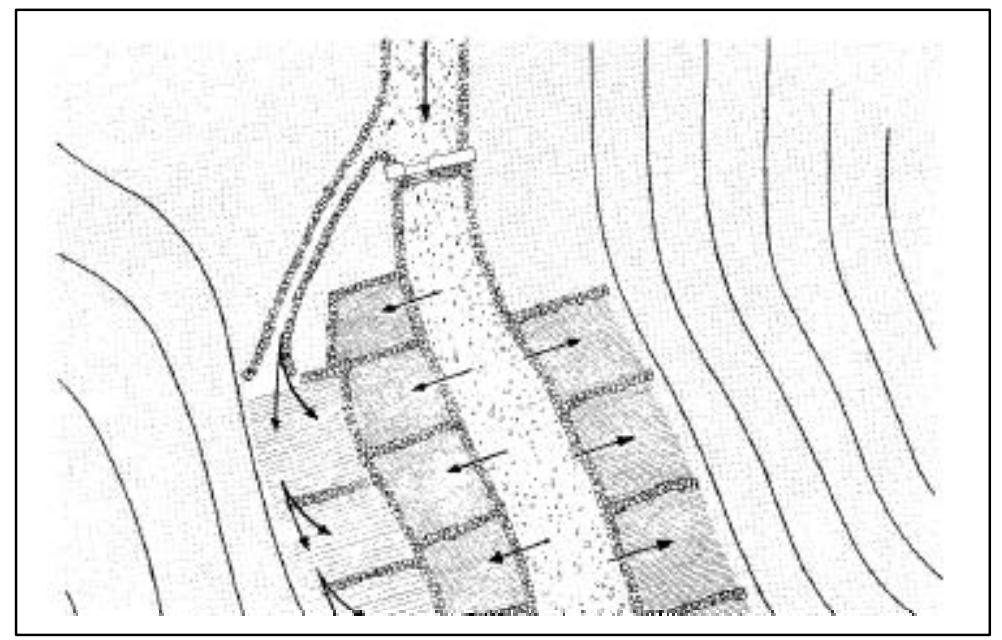

Fig. 7. Flood water diversion scheme: Design of water-spreading dams in large, deep wadis (Nabataean system).

Source: Evenari \& Koller 1956, from Cox and Atkins 1979

\subsection{ASIA}

\subsubsection{The Middle East}

The outstanding importance of the Middle East in the development of ancient water harvesting techniques is unquestioned. Archeological evidence of water harvesting structures appears in Jordan, Syria, Iraq, the Negev and the Arabian Peninsula, especially Yemen. 
In Jordan, there is indication of early water harvesting structures believed to have been constructed over 9,000 years ago. Evidence exists that simple water harvesting structures were used in Southern Mesopotamia as early as in 4,500 BC (Bruins et al. 1986).

Internationally, the most widely known runoff-irrigation systems have been found in the semi-arid to arid Negev desert region of Israel (Evenari et al. 1971). Runoff agriculture in this region can be traced back as far as the 10th century BC when it was introduced by the Israelites of that period (Adato 1987). The Negev's most productive period in history however, began with the arrival of the Nabateans late in the 3rd century B.C. (Fig. 8). Runoff farming continued throughout Roman rule and reached its peak during the Byzantine era.

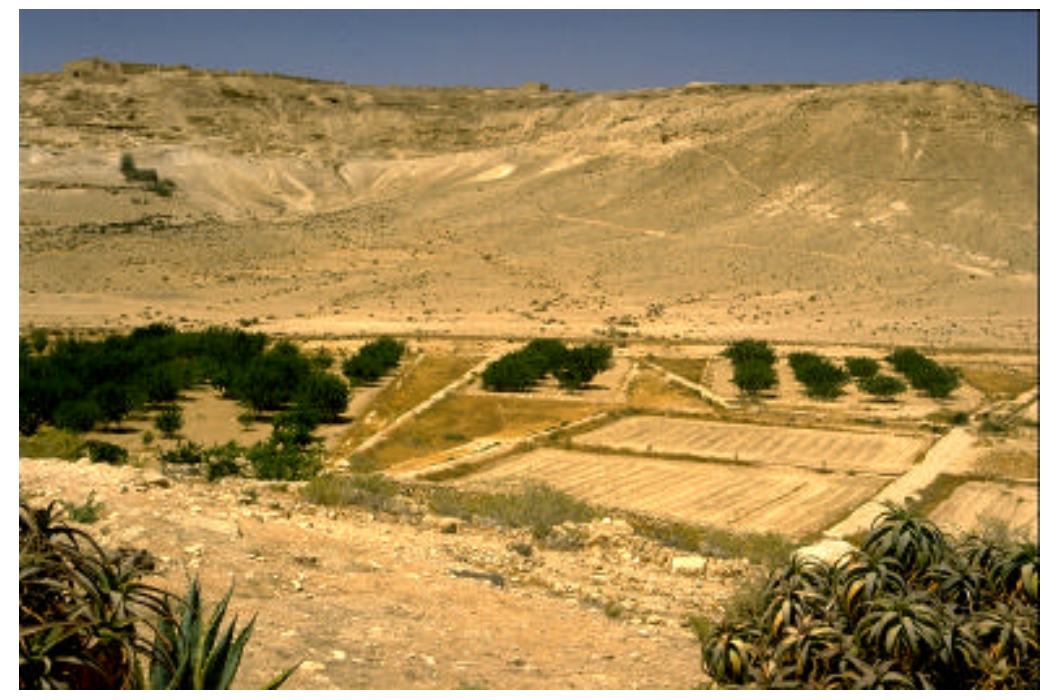

Fig. 8. Reconstruction of an ancient water harvesting system ("Hillsite conduit system") in Wadi Avdat/Negev (100 mm annual precipitation, CCR 175:1, 2 ha cropping area). Photo: Prinz

In North Yemen, a system dating back to at least 1,000 B.C. diverted enough floodwater to irrigate 20,000 hectares $(50,000$ acres) producing agricultural products that may have fed as many as 300,000 people (Adato 1987, Eger 1988). Farmers in this same area are still irrigating with floodwater, making the region perhaps one of the few places on earth where runoff agriculture has been continuously used since the earliest settlement (Bamatraf 1994).

\subsubsection{Saudia Arabia}

In the South Tihama of Saudi Arabia, flood irrigation is traditionally used for sorghum production. Today, approximately 35,000 ha land, supporting 8,500 to 10,000 farm holdings, are still being flood irrigated (Wildenhahn 1985).

\subsubsection{Pakistan}

In Baluchistan two water harvesting techniques were already applied in ancient times: the "Khuskaba" system and the "Sailaba" system. The first one employs bunds being built across the slope of the land to increase infiltration. The latter one utilizes floods in natural water courses which are captured by earthen bunds (Oosterbaan 1983). Fig. 9 depicts such a water spreading system in Pakistan. 


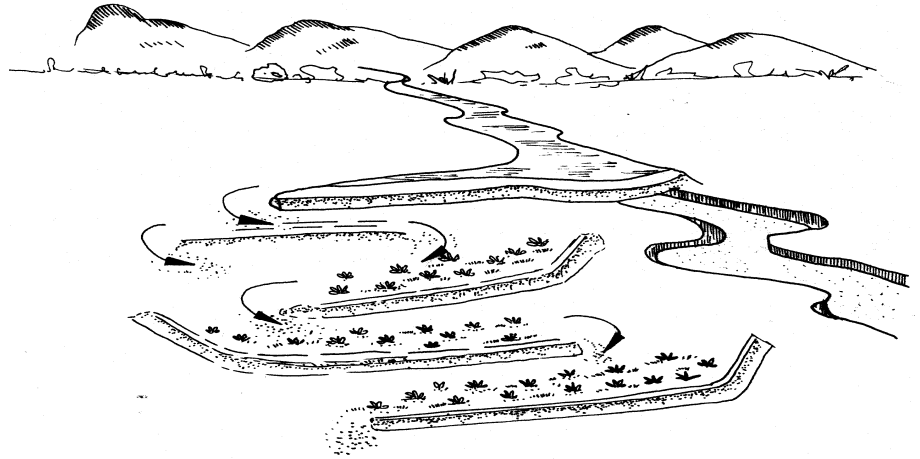

Fig. 9. Water spreading system in Pakistan to divert flood water for agricultural use. Source: Adapted from French and Hussain 1964

\subsubsection{India}

In India, the "tank" system is traditionally the backbone of agricultural production in arid and semi-arid areas. The tanks collect rainwater and are constructed either by bunding or by excavating the ground. It is estimated that 4 to 10 hectares of catchment are required to fill one hectare of tank bed. In West Rajastan, with desert-like conditions having only $167 \mathrm{~mm}$ annual precipitation, large bunds were constructed as early as the 15th century to accumulate runoff. These "Khadin" create a reservoir which can be emptied at the end of the monsoon season to cultivate wheat and chickpeas with the remaining moisture (Kolarkar et al. 1983). A similar system called "Ahar" developed in the state of Bihar (UNEP 1983, Pacey and Cullis 1986). Ahars are often built in series. It was observed that brackish groundwater in the neighbourhood of Ahars became potable after the Ahar was built, due to increased supply of rain water.

\subsubsection{China}

A very old flood diversion technique called "warping" is found in China's loess areas which harvests water as well as sediment.

\subsection{AFRICA}

\subsubsection{North Africa}

Since at least Roman times water harvesting techniques were applied extensively in North Africa. Archeological research by the UNESCO Libyan Valleys team revealed that the wealth of the "granary of the Roman empire" was largely based on runoff irrigation (Gilbertson 1986). The team excavated structures in an area several hundred kilometers from the coast in the Libyan pre-desert, where the mean annual precipitation is well below fifty millimeters. The farming system here lasted well over 400 years and it sustained a large stationary population, often wealthy, which created enough crops to generate even a surplus. It produced barley, wheat, olive oil, grapes, figs, dates, sheep, cattle and pigs. The precipitation is variable, falling in just one or two rain storms, often separated by droughts several years long. (There is no evidence of climatic change since Roman period).

Many other examples of the application of traditional techniques in North Africa can be given:

In Morocco's Anti Atlas region, Kutsch (1982) investigated the traditional and partly still practised water harvesting techniques. He found a wealth of experience and a great variety of locally well adapted systems.

In Algeria, the "lacs collinaires", the rainwater storage ponds are traditional means of water harvesting for agriculture. The open ponds are mainly used for watering animals.

In Tunesia, the "Meskat" and the "Jessour" systems have a long tradition, but are also still practised. The "Meskat" microcatchment system consists of an impluvium called "meskat", of about $500 \mathrm{~m}^{2}$ in size, and a "manka" or cropping area of about $250 \mathrm{~m}^{2}$ (Fig.10). Thus, the CCR is 2:1. Both are surrounded by a 20 $\mathrm{cm}$ high bund, equipped with spillways to let runoff flow into the "manka" plots. 


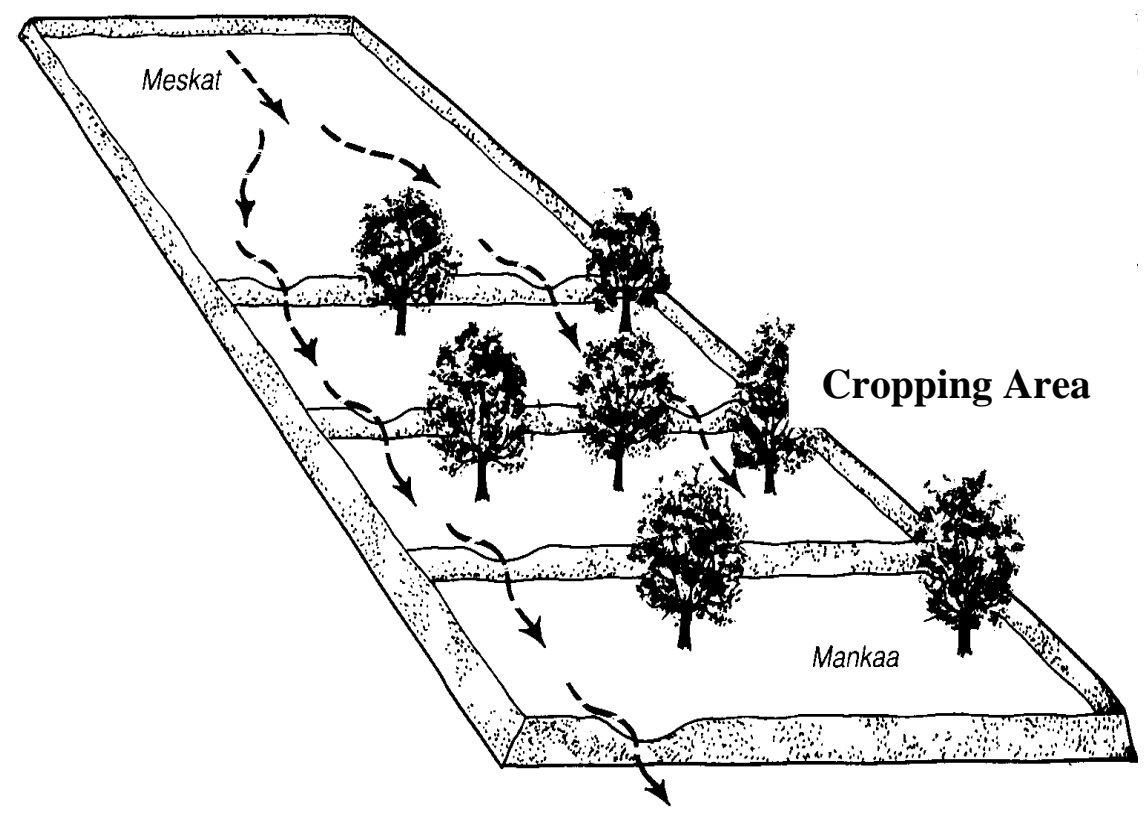

Fig. 10. The Tunesian "Meskat" microcatchment system. Source: Adapted from El Amami 1983

This system can provide the fruit tree plantation with about 2,000 $\mathrm{m}^{3}$ extra water during the rainy season. Whereas the "Meskats" are mainly found in the Sousse region, the "Jessour" are widespread in the South (Matmata).

The "Jessour" system is a terraced wadi system with earth dikes ("tabia") which are often reinforced by dry stone walls ("sirra"). The sediments accumulating behind the dikes are used for cropping (Fig 11). Most "Jessour" have a lateral or central spillway.

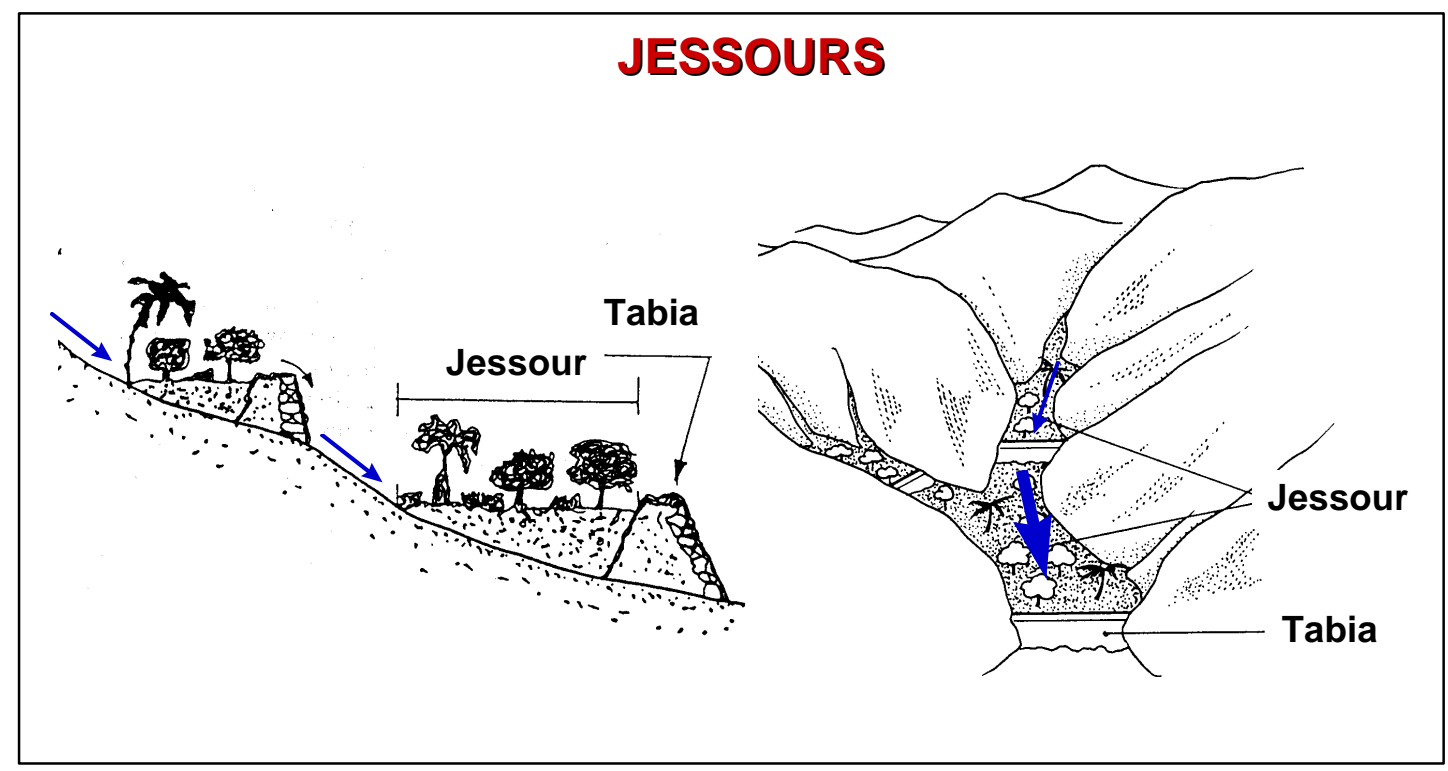

Fig. 11. A row of "Jessour" in the South of Tunesia. Source: Adapted from El Amami 1983 
The "Mgouds" in Central Tunisia are channel systems used to divert flood water from the wadi to the fields (Tobbi 1994).

In Lybia, as mentioned before, archeological and historical studies have revealed the development and expansion of a highly successful dry (runoff based) farming agriculture during Roman times. On the slopes of the western and eastern mountain ranges some of these techniques continue to be practised ( $\mathrm{Al}$ Ghariani 1994).

In Egypt, the North-West coast and the Northern Sinai areas have a long tradition in water harvesting. Remnants from Roman times are frequently found (El-Shafei 1994). Some wadi terracing structures have been in use for over centuries (Fig. 12).

\subsubsection{Sub Saharan Africa}

Traditional techniques of water harvesting have been reported from many regions of Sub Saharan Africa (Reij et al. 1988, Critchley et al. 1992a, Critchley et al. 1992b, van Dijk \& Reij 1993).

A few of those systems shall be described here in more detail:

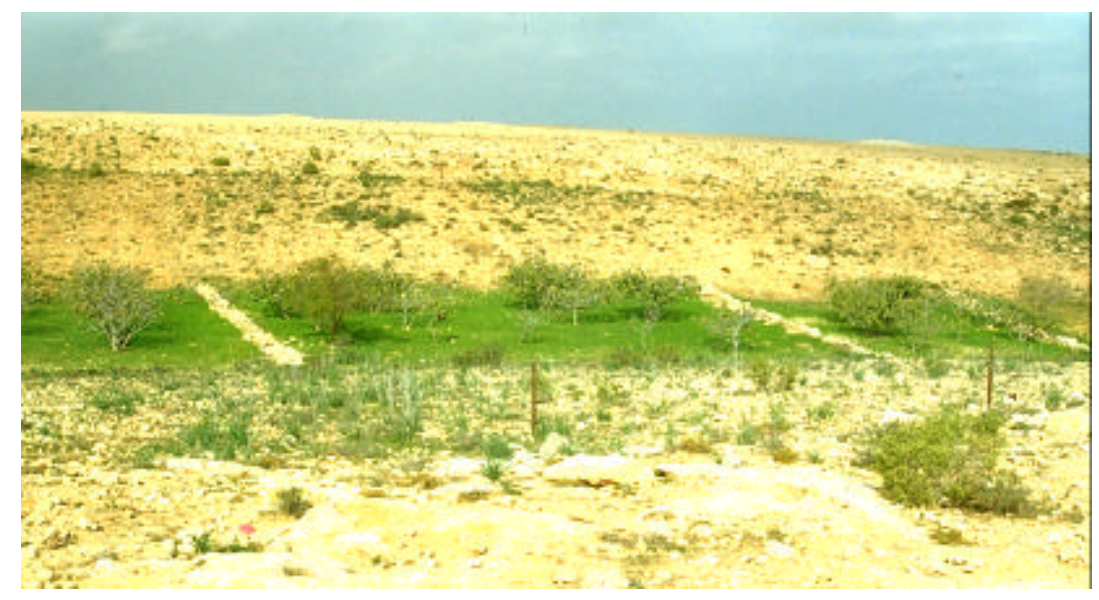

Fig. 12. Wadi Terraces from Roman times still in use in Marsa Matruh area (NW coast, Egypt). Photo: Prinz

The central rangelands of Somalia are home to two small scale water harvesting systems which have been important local components of the production system for generations:

The Caag system is a technique used to impound runoff from small water courses, gullies or even roadside drains (Fig. 13). Sometimes ditches are dug to direct water into the fields. Runoff is impounded by the use of earth bunds. The entire plot may be a hectare or more in size. The alignment of the bunds is achieved by eye and by experience. In this system, runoff is impounded to a maximum depth of 30 $\mathrm{cm}$. If water stands for more than five days or so, the bund may be deliberately breached to prevent waterlogging (Reij et al. 1988).

Fig. 13. The "Caag" system in Hiraan region, Central Somalia (150-300 mm annual rainfall). (Source: Critchley et al. 1992b)

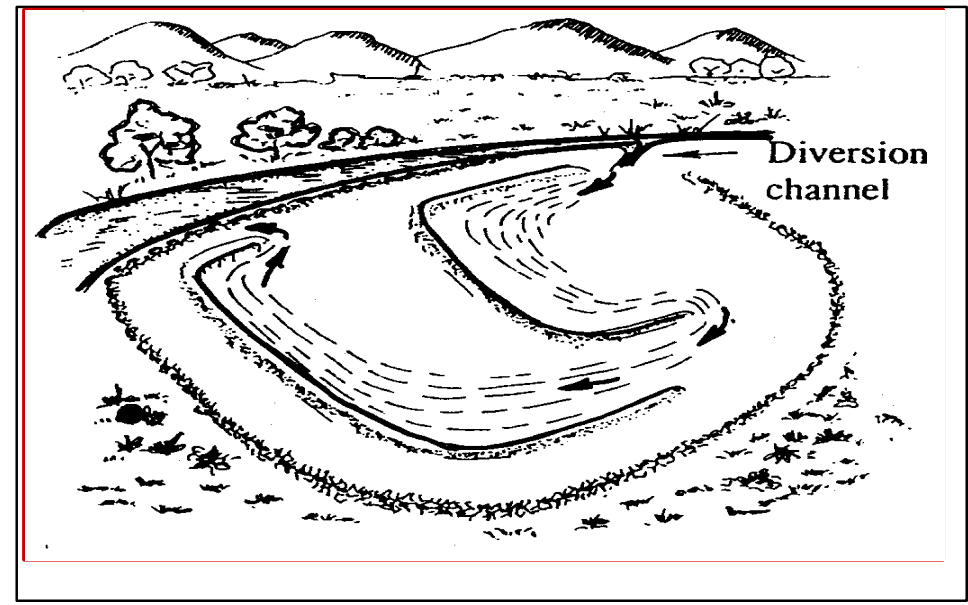


The Gawan system is used where the land is almost flat and where is less runoff. Small bunds are made which divide plots into "grids" of basins. Individual basins are in the order of $500 \mathrm{~m}^{2}$ or above in size.

In both of these systems, sorghum is the usual crop grown, although cowpeas are also common. If the rains permit, two crops are taken each year (Reij et al. 1988).

In Sudan, various types of "Haffirs" have been in use since ancient times. Their water is used for domestic and animal consumption as well as for pasture improvement and paddy cultivation (UNEP 1983).

The Haussa in Niger's Ader Doutchi Maggia have altered a considerable area with rock bunds, stalks and earth to divert water to their fields.

The Mossi in Burkina Faso also constructed rock bunds and stone terraces in the past.

Somerhalter (1987) made mention of the existance of various traditional water harvesting techniques (although on a small scale) in the Ouaddai area in Chad.

The "Zay" system in Burkina Faso is a form of pitting which consists of digging holes that have a depth of $5-15 \mathrm{~cm}$ and a diameter of $10-30 \mathrm{~cm}$. The usual spacing is between $50-100 \mathrm{~cm}$ (Wright 1985). This results in a CCR of about $1-3: 1$. Manure and grasses are mixed with some of the soil and put into the zay (Fig. 14). The rest of the soil is used to form a small dike downslope of the pit. Zay are applied in combination with bunds to conserve runoff, which is slowed down by the bunds.

Many other traditional water harvesting systems existed or still exist, but the basic problem is that knowledge and information in this zone is extremely limited and fragmentary (Reij et al. 1988).

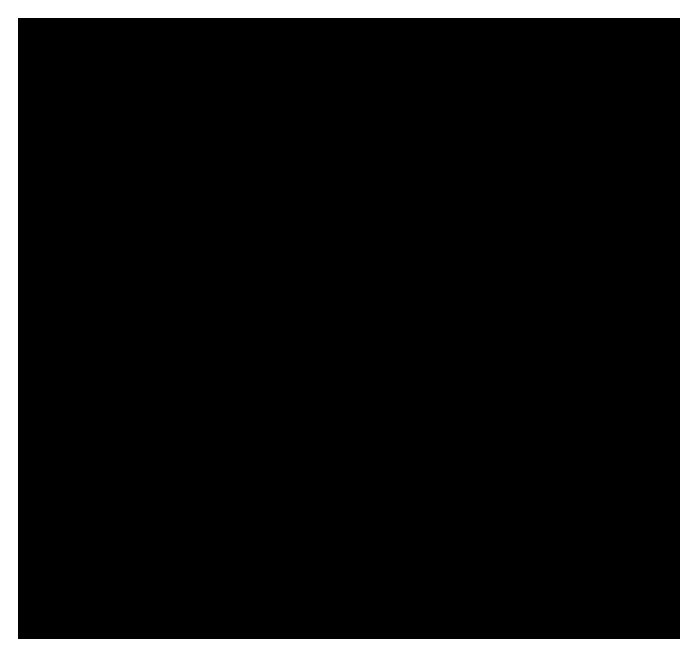

Fig. 14. The zay microcatchment water harvesting system in Burkina Faso Source: Reijntjes et al. 1992

\subsection{AMERICA: SOUTHWEST USA AND NORTH MEXICO}

Traditional water harvesting was practised in the Sonoran desert by the Papago Indians and other groups. The Papago fields were located on alluvial flats, fan aprons and fan skirts of ephemeral washes, where large catchments then became concentrated. Brush weirs were used to spread the floodwaters (Nabhan 1984). Elsewhere, fields were irrigated by gravity-fed channels (arroyos) leading water from earth and stick diversion weirs (Nabhan and Sheridan 1977, Doolittle 1984). For the Eastern Sonora Region of North Mexico, an evolution in techniques took place. Brush water spreaders were gradually replaced by rock bunds as the fields' clearing was increased and the supply of brush was depleted. A highly sophisticated distribution system was demonstrated by the flood water diversion system of Chaco Canyon, New Mexico (Fig. 15). 


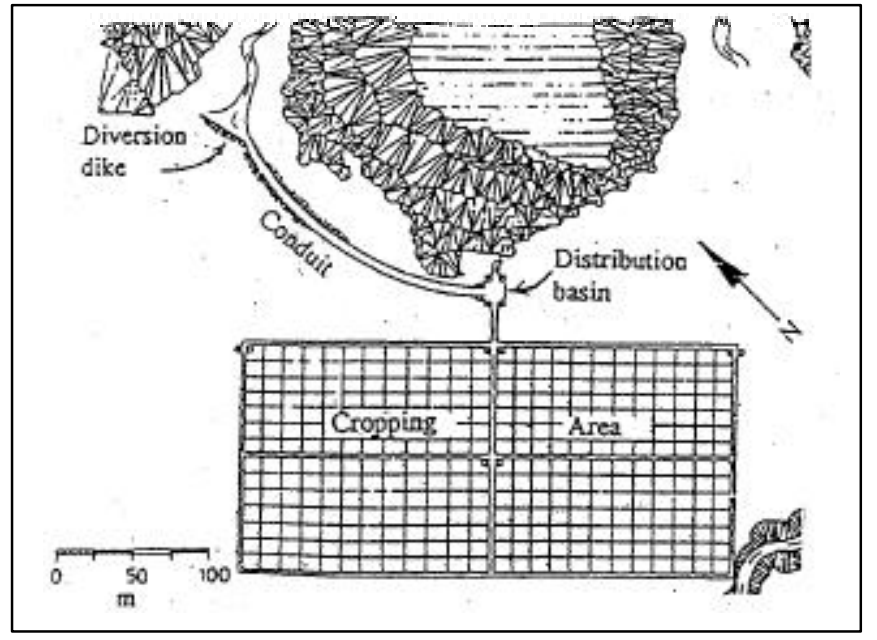

Fig. 15. Runoff farming system in Chaco Canyon, New Mexiko (175 mm annual precipitation, $\quad \mathrm{CCR}=470: 1,9$ ha horticultural area) Source: Vivian 1974

\subsection{CONCLUSIONS FROM THE PAST ROLE OF WATER HARVESTING}

It is evident from archeological findings and historical descriptions that water harvesting played a dominant role in many arid and semi-arid regions to sustain agricultural production.

Why did its role diminish, why did so many systems fail on the long run?

Why do we see poor land use, and even a desertified landscape, where formerly a flourishing agriculture existed?

There are no simple answers to these questions and we have to admit that the causes are in most instances not fully known or understood.

The various causes mentioned are:

? The decline of central powers (e.g. of the Byzantine empire in the Middle East) due to political shifts

? warfare incl. civil war

? economic changes, e.g. in competitiveness on local or export markets

? social changes, incl. availability of cheap labour, aspirations or attitudes of the people involved in water harvesting

? climatic change (increasing aridity, change in precipitation regime)

? increasing salinity

? decreasing soil fertility (nutrient status)

? soil erosion (wind and water erosion).

In the case of the successful floodwater farming system in the Libyen pre-desert mentioned above, the explanations for failing focus upon size and competitiveness of the markets in the coastal cities for the agricultural produce which apparently changed after the arrival of the Islamic armies in $642 \mathrm{AD}$ and the conversion to Islam. But there is also some evidence that a slow salinization and some soil erosion negatively influenced the agricultural production (Gilbertson 1986).

\section{The Development of Water Harvesting Since 1950}

\subsection{GENERAL}

During this century, only very few water harvesting activities in research or implementation were undertaken before 1950. Australian farmers had already started to harvest water for domestic and animal use after World War I. During World War II, some water harvesting activities were carried out on islands with high rainfall (e.g. on the Caribbean island of Antigue). After 1950 water harvesting received renewed 
interest on the research level as well as in the implementation sector, partly due to the successful reconstruction of ancient water harvesting farms in the Negev by Evenari and collegues (Evenari et al. 1971). Most of the research activities have been carried out in Israel, Australia, the USA and India, but efforts in other countries should not be neglected.

Some institutional or research activities related to water harvesting from recent decades shall be summarized here:

\subsection{DEVELOPMENT IN ASIA}

\subsubsection{Israel}

The Israeli experience was reviewed by Ben Asher (1988) within the World Bank Sub-Saharan Water Harvesting Study. Their research work focused on

- testing of specific water harvesting techniques, especially microcatchments (Fig. 16)

- studying soil surface characteristics, especially crust formation

- studying and modelling runoff behaviour

- analyzing the economy of water harvesting techniques.

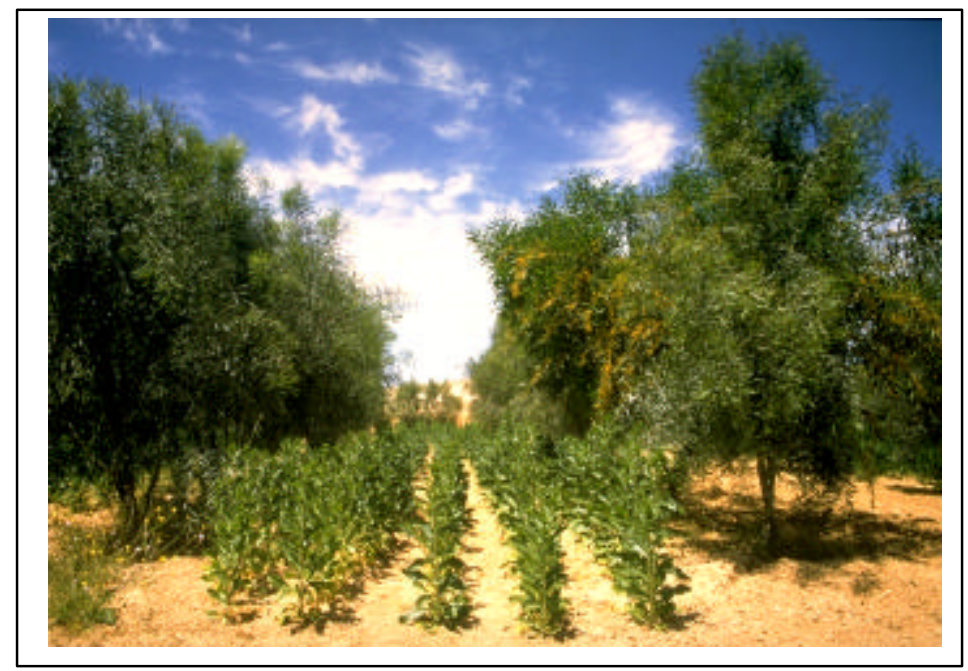

Fig. 16. Water harvesting research on agroforestry in Wadi Mashash, Israel.

Photo: Lövenstein

The first aspect deals with the water content regime within the planted area, while the other one has to do with the availability of runoff to the planted area. On Wadi Mashash farm, a long term project with the aim of developing a model agroforestry system having medium-sized catchment water harvesting was carried out (Zohar et al. 1987, Lövenstein 1994). Developing the design criteria of microcatchments and limans is also receiving attention (Boers 1994, Fig. 17). 


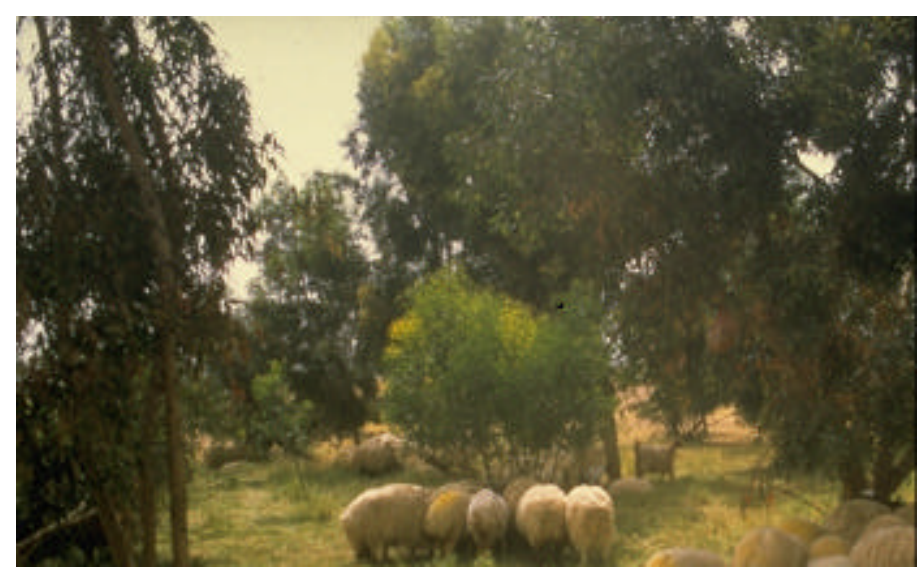

Fig. 17. Sheep grazing a liman at Wadi Mashash Experimental Farm, Negev, Israel. Photo: Lövenstein

\subsubsection{Jordan}

In Jordan, earth dams have been constructed since 1964 in order to force runoff to infiltrate for pasture improvement. At the final stage the total area flooded shall be about 2,500 ha. (Al-Labadi 1994). In 1972, a project known as "Jordan Highland Development Project" was initiated. Rock dams, contour stone bunds, trapezoidal bunds and earth contour bunds are used to increase soil moisture around the trees planted on steep lands (Shatanawi 1994). The total area utilized since its inception is estimated to be 6,000 hectares.

Between 1985 and 1988, Jordan's Ministry of Agriculture, in collaboration with ACSAD, used contour terraces and ridges for pasture and range improvement in the Balama district. Better growth of olive, almond and pistachio was recorded (Shatanawi 1994) on the experimental site. In 1987 the Faculty of Agriculture of the University of Jordan initiated the construction of earth dams to impound and store flood waves for irrigation purposes. The catchment area is about $70 \mathrm{~km}^{2}$ and the annual precipitation is $150 \mathrm{~mm}$. Currently there is a collaborative research project aimed at developing an integrated optimization prediction model for water harvesting, storage and utilization in dry areas in Jordan. Oweis \& Taimeh (1994) report on further water harvesting reseach activities in Jordan.

\subsubsection{Other Middle East Countries}

In the Dei-Atiye community of Syria, rainwater harvesting was established in 1987 on an area of 130 ha. The project site was sub-divided into four parts for tree crops, range plants, cereals and runoff research (Ibrahim 1994). The International Centre for Agricultural Research in the Dry Areas (ICARDA) in Syria, is currently working on the improvement of various WH techniques and on the identification of waterharvesting areas suitable for various West Asian and North African (WANA) environments (Oweis and Prinz 1994).

In the North-West Arabia, a local system known as "Mahafurs" is still in use. This system is simply a shallow excavation of $20-100 \mathrm{~m}$ in diameter surrounded on three sides by earthen bunds $1-4 \mathrm{~m}$ high. The open side is pointed in the direction of water flow inside the wadi bed and used to collect water for animal consumption and moisture for plant production (Barrow 1987).

In Afghanistan, composite microcatchments have been in use for a long time. In a survey conducted in the early 1970s, over 70,000 ha of Meskat-type systems used for growing fruit trees were reported.

\subsubsection{India}

At the Centre for Arid Zone Studies in Todhpur and at the International Centre for Research in the SemiArid Tropics (ICRISAT) in Hyderabad, various research projects on water harvesting related programmes have been going on since 1975 .

One of the findings at these research stations was that alfisols have greater runoff potential than vertisols and therefore the scope of profitable yield responses is greater on alfisols (Ryan et al. 1980). 
In the eighties, ICRISAT also developed a system of broad beds and grassed drains which collect runoff in storage tanks during the rainy season to be used for supplementary irrigation during the dry season. To apply the water to the plants, bullock-drawn water casts equipped with sprinklers are used. Research results show that crop yields increased between two and fivefold (Barrow 1987, Fig. 18).

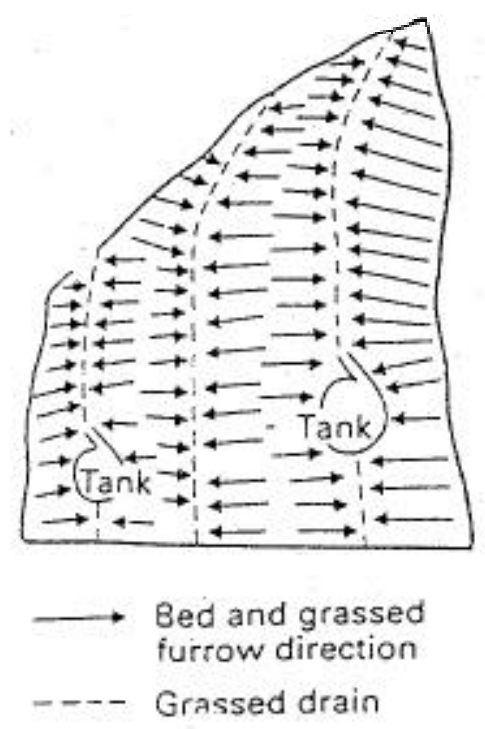

Fig. 18. The broad-bed and furrow runoff collection system of ICRISAT, Hyderabad, India. Source: Barrow 1987

ICRISAT also carried out another research work aimed at adapting a traditional tank irrigation technology to modern socio-economic conditions. The concept of this work was to improve tank management with water control and to find an alternative system of runoff and erosion controlling land management for groundwater recharge and sustained well irrigation (Von Oppen 1985). These concepts have been found to have great potential and research is still going.

\subsubsection{Other Countries}

In tropical Asia, especially southern India and Sri Lanka, earth bunds and excavated hollows have been used for runoff retention during the rainy seasons for millenia. Tank storage permits farmers to grow a second dry season irrigated crop in addition to rainfed agriculture. Tanks are sited randomly so that any overland flow from one is caught by others downslope. In case of siltation, labourers are hired to remove the silts and spread them on the cropping land during the dry season (Barrow 1987).

\subsection{DEVELOPMENT IN AFRICA}

\subsubsection{North Africa}

In different parts of Libya, experimental sites of contour-ridge terracing covering more than 53,000 ha have recently been established (Al-Ghariani 1994).

In 1990, the government of Tunisia started the implementation of the National Strategy of Surface Runoff Mobilization which aims, among other things, at building 21 dams, 203 small earth dams, 1,000 ponds, 2,000 works to recharge water tables and 2,000 works for irrigation through water spreading by the year 2,000 (Achouri 1994). Up to 1984, "Meskats" covered 300,000 ha where 100,000 olive trees were 
planted; "Jessours" covered 400,000 ha (Tobbi 1994). Modern spate irrigation techniques have been applied in Central Tunisia since 1980, covering an area of 4,250 ha and harvesting about $20 \mathrm{Mm}^{3}$ of water annually.

In Wadi El-Arish region of Egypt, stone dykes were used to direct the runoff water flow for irrigation purposes. Also cisterns, which store water meant for animal and human consumption as well as for supplemental irrigation, are common in Egypt. The number of cisterns has increased from less than 3,000 in 1960 to about 15,000 in 1993 with a capacity of about 4 million $\mathrm{m}^{3}$ (Shata and Attia 1994).

In the North-West region of Egypt a GTZ/FAO sponsored project on land use planning including water harvesting activities was carried out (El-Shafey).

In Yemen, small dams storing runoff for later use in irrigation or rural supply have been constructed since the beginning of the eighties; the total storage capacity is between 50,000 to $90,000 \mathrm{~m}^{3}$ (Bamatraf 1994).

"Matfia" is an old technique of storing water for human and animal consumption in Morocco, which still continues (Tayaa 1994). Expensive modern technology, including the use of reinforced concrete has now been introduced in constructing the cisterns, although the local people are less interested in these large and expensive systems. Since 1984, Morocco has started constructing dams ("Barrages Collinaires") to harvest flood water. The upstream catchment area under these dams ranges from 500 to 10,000 hectares. As of 1988, thirty five of these dams had been constructed. They provide irrigation water for about 160,000 animals and 3,000 ha of cultivated plots.

\subsubsection{Sub-Saharan Africa}

An agroforestry project (PAF) aimed at improving tree planting using microcatchments was initiated by OXFAM in 1979 at the Yatenga Province of Burkina Faso. In 1982, this was modified to contour stone bunds (aligned along the contour) and used for crop production. Later, it was combined with the traditional "zai" systems which has improved its acceptability by the local farmers. It was reported that by the end of 1989, some 8,000 hectares in over 400 villages had been modified with stone bunds (Critchley et al. 1992a).

Various research projects are being carried out on the Central Plateau of Burkina Faso by many research institutes. Emphasis in the region is mainly put on improving stone bund construction, studying the effects of stone bunds on runoff, erosion and yields, rehabilitation of degraded catchment areas and combination of stone bunds with tied ridges (Buritz and Dudeck 1986).

In the Hiraan Region of Somalia the local water harvesting techniques known as "Caag" and "Gawan" still continue (Abdi 1986).

In Ethiopia, the Sudan and Botswana, small check-dams made of earth are used to catch moderate overland flow passing down slight slopes. They are called "haffirs" and support crops planted upslope (Barrow 1987).

In 1985, the Institut für Wasserbau und Kulturtechnik (Institute of Hydraulic Structures and Rural Engineering), University of Karlsruhe, Germany, started a project in Mali with the aim of testing the feasibility of runoff irrigation in the Sahel region. The total contributing area was 127 ha and the collecting area was 3.3 ha so that the CCR was 40:1. These systems have now being operated for nine years and the harvests for sorghum are three times those for comparable sites using rainfed agriculture (Klemm 1990, Fig. 19).

In 1989-91 an EC financed study was carried out by the same Institute which aimed at the development of a methodology of identifying areas suitable for runoff irrigation. Maximum use was made of data obtained from satellite systems (Landsat-TM and SPOT) on the basis of site inspections in W-Mali and N Burkina Faso. A methodology was developed which integrates meteorological, pedological, topographic and socio-economic data sets in an user-friendly GIS, distinguishing between the suitability of a site for microcatchments or macrocatchments. (Tauer and Humborg 1992; Prinz et al. 1994). 


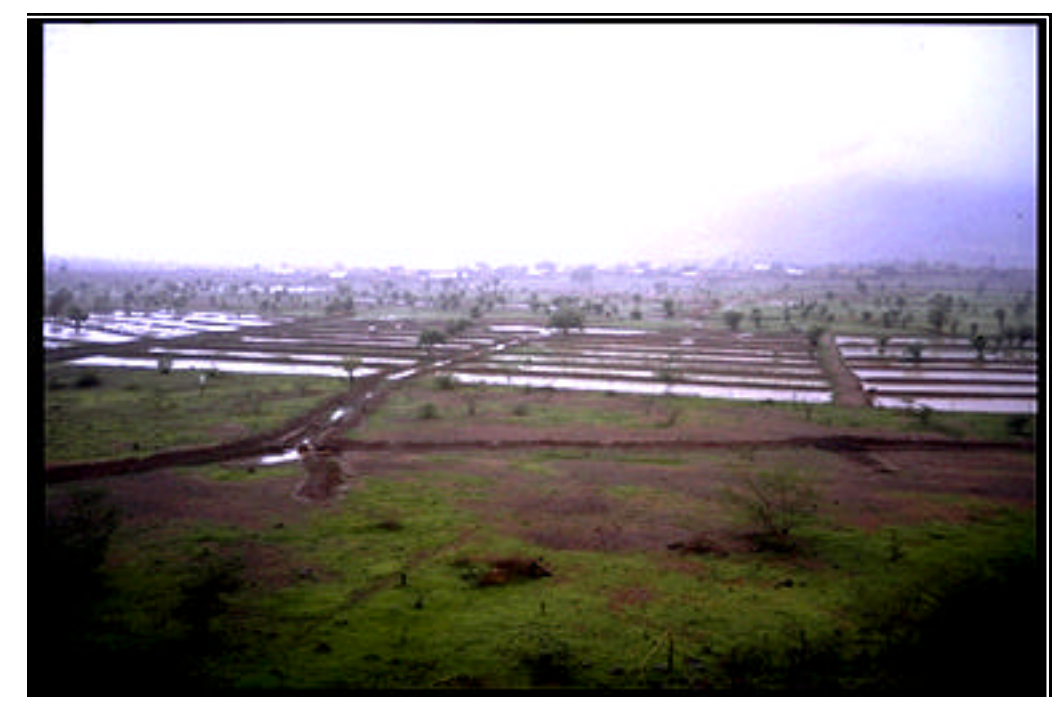

Fig. 19. A macrocatchment water harvesting system in Mali, Kayes Province. Photo: Klemm

establishment (Antinori and Vallerani 1994).

In 1988, special ploughs developed by Italian scientists were used in Niger for the implementation of (Vallerani type) microcatchments on a large scale. Results from these plots showed excellent rates of tree

A set of test plots on improved trapezoidal bunds in Baringo, Kenya has been constructed. This improved version consists of earth bunds which surround the plot and diverge as collection arms upslope to increase the catchment area (MoALD 1984).

In 1984, a self-help project sponsored by Oxfam and known as Turkana Water Harvesting Project, was started in the Turkana district of Kenya. It was aimed at developing systems of water harvesting for crop production, while also introducing animal ploughing. This project has evolved into a long-term development programme involving women and is concerned mainly with pastoral production which is the main occupation of the villagers (Critchley et al. 1992a).

In 1990, it became known as Lokitaung Pastoral Development Project and a local management board whose members are drawn from the local traditional institutions have since been managing the project.

\subsection{NORTH AND SOUTH AMERICA}

In the United States of America, research emphasis is on runoff inducement from catchments and the reduction of seepage losses (Frasier 1994). Combined and supplementary systems have been tested (Fig. 20).

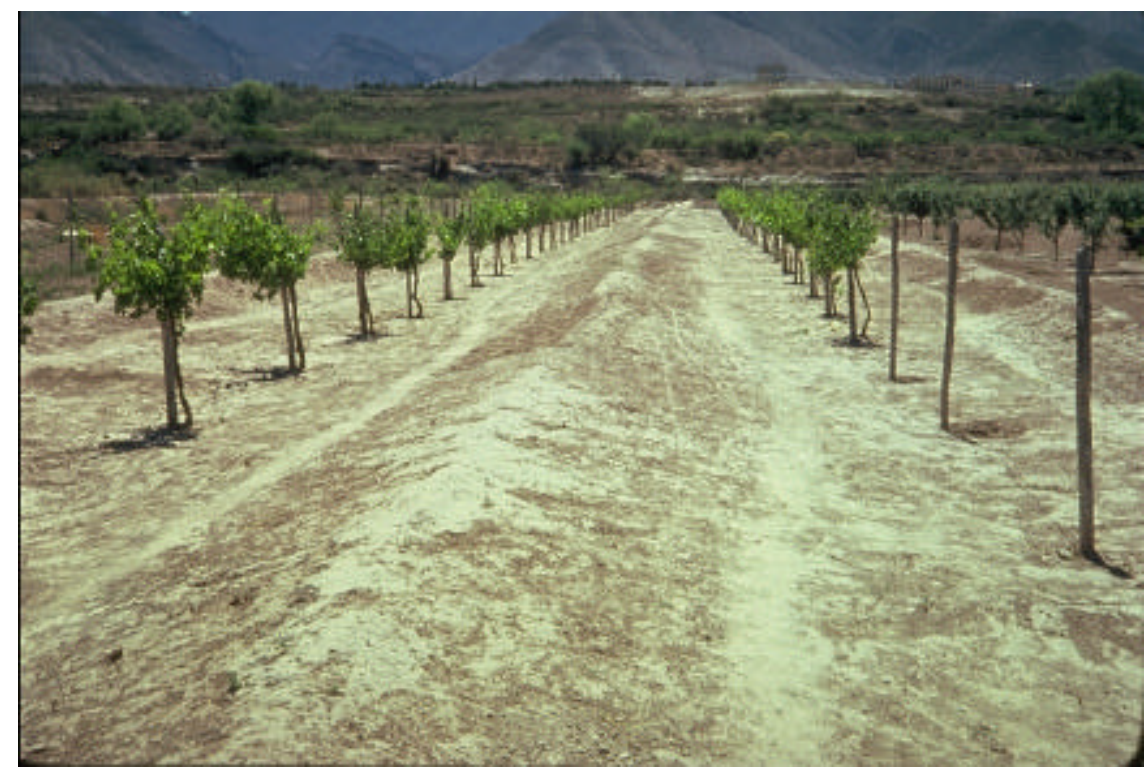

Fig. 20. Inter-row water harvesting with treated catchment in North-Central Mexico. Photo: Frasier 
The traditional check-dam known as "Bolsa" is still used in the cultivation of crops in some parts of Mexico. "Bolsas" are earthen-walled basins which catch water diverted from seasonal creeks ("arroyos") (Barrow 1987). After the arroyos have wetted the bolsas, plants are cultivated on the bolsas and mulch of dry sand is spread on it to avoid evaporation.

In NE-Brazil, a modified form of the "zay" systems was introduced in 1986.

\subsection{DEVELOPMENT IN AUSTRALIA}

In Western Australia, topography modification in the form of catchment treatment has been practised for a long time. These are known as "roaded" catchments. They consist of parallel ridges ("roads") of steep, bare and compacted earth, surveyed at a gradient that allows runoff to occur without causing erosion of the intervening channels (Burdass 1975, Laing 1981). In 1980, it was estimated that there were more than 3,500 roaded catchment systems in Western Australia, and many of them have a top dressing or a layer of compacted clay to increase the runoff efficiency (Frasier 1994).

\section{The Future Role of Water Harvesting}

\subsection{GENERAL CONSIDERATIONS}

When analyzing agricultural production and natural resources utilization in (semi-) arid areas, some conclusions, especially regarding water harvesting, can be drawn:

(1) Government policy (within the agricultural sector) is mostly directed towards cash crop production. Cash crops, in order to be profitable, need a reliable water supply which can best be guaranteed by conventional irrigation (not water harvesting). Therefore support concerning extension services, loans, marketing support etc. are given primarily to (exportable) cash crops.

(2) Substantial amounts of rainfall in (semi-) arid areas are lost (e.g. by evaporation from soil surfaces), which could be utilized for agricultural production.

(3) In a number of countries where water harvesting played a major role in the past (e.g. North Yemen), its importance has declined (see Chapter 3.5)

(4) Despite considerable efforts undertaken in recent years (especially by international/Western donors) to promote and disseminate water harvesting techniques, the overall success is much less than expected (Siegert 1994). Figure 21 shows the relationship between some production issues and water management levels in agriculture.

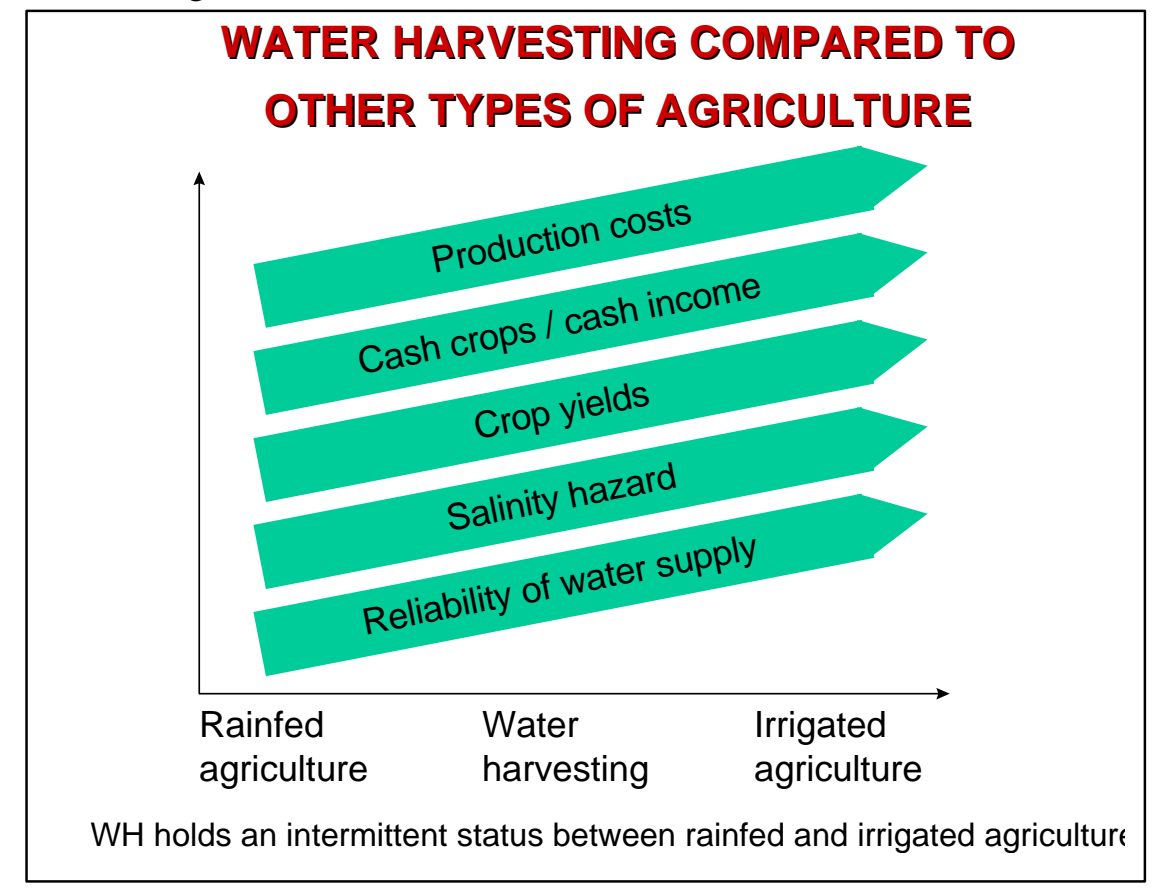

Fig. 21. Water harvesting and some production issues 


\subsection{CHOICE OF WATER HARVESTING TECHNIQUES}

Numerous water harvesting projects have failed because the technology used proved to be unsuitable for the specific conditions of the site (Siegert 1994). Each of the water harvesting methods has its advantages and limitations which can be summarized as follows:

(1) Water harvesting for animal consumption

In developing countries, the building or reactivation of cisterns and other rainwater tanks for animal consumption can save water which othewise has to be lifted or pumped from groundwater or carried over long distances.

In "developed" countries (the USA, Australia) the search for cheap, durable soil treatment substances (e.g. sodium methyl silanolate) or ground covers continues (Arar 1993). It is expected that the costs for such treatments will be low enough in the future to treat larger areas and to obtain toxic-free runoff water.

(2) Inter-row water harvesting

In regions with not less than $200 \mathrm{~mm}$ (winter-rains) to $300 \mathrm{~mm}$ (summer-rains) annual precipitation, interrow water harvesting will have a high potential in low-income as well as in high-income countries.

Contour ridges or bunds can be formed using hand tools, animal-drawn equipment or tractors, and therefore this technique is widely applicable for use in orchard establishment, general tree planting or for the cultivation of annual crops.

Under high-input conditions (e.g. in the USA), the space between the rows is often compacted and chemically treated to increase runoff.

(3) Microcatchment systems

Most of the research on microcatchment development has been done in Israel. A cost/benefit analysis carried out on negarin-type microcatchments in Israel in an area with less than $150 \mathrm{~mm}$ annual rainfall showed however, that the specific water supply was not sufficient for economic production (Oron et al. 1983). In this case, larger forms of Negarin microcatchment in higher rainfall areas seem to be more appropriate. The various other microcatchment types have their specific advantages. The quickest way to produce microcatchments is with the 'Dolphin' plough, being able to 'dig' 5000 microbasins per day, equivalent to a treated surface of 10 ha, with a water holding capacity of 6001/basin (Antinori and Vallerani 1994).

(4) Medium-sized catchment water harvesting. Medium-sized and microcatchment systems are regarded to have a high potential in the future. The desertification processes in many (semi-) arid regions have created large denuded surfaces, which are extremely difficult to revegetate.

These surfaces often yield high quantities of runoff water, which could be utilized with MSC-WH systems, especially with 'hillside conduit systems'. Many problems were experienced with trapezoidal bunds; "liman" terraces worked well in the past, if hydrologically calculated correctly, and will be a positive asset for future development (re-vegetation) in pre-desert regions.

(5) Large catchment water harvesting systems. If the development of those area systems can be combined with flood protection works for ephemeral streams, then a limited increase can be forecasted.

\subsection{NEW DEVELOPMENTS}

During recent years some technological developments took place in regard to water harvesting which might have some impact on the future role of $\mathrm{WH}$ in general:

(1) Supplemental water system

Runoff water is collected and stored offside for later application to the cropped area using some irrigation method. The water stored allows a prolongation of the cropping season or a second crop.

(2) Dual purpose systems

In a dual purpose system the runoff water flows first through the crop area, then the excess water is stored in some facility for later irrigation use.

In Arizona, USA, runoff irrigation was combined e. g. with trickle irrigation, using sealed soil surfaces to increase runoff rates.

(3) Combined systems 
If the irrigation water from aquifers or from rivers/reservoirs is not sufficient for year-round irrigation, a combination with runoff-irrigation (during the rainy season) is feasible. The combination of runoff- and furrow irrigation is reported from North Central Mexico (Frasier 1994).

(4) Modelling

If more information on hydrological, soil and crop parameters is available, models can be developed and applied to water harvesting for certain environments (Boers 1994).

\subsection{CONCLUSIONS}

Water harvesting has proved to be a valuable tool especially in dry marginal areas

(1) to increase crop yields and reduce cropping risk

(2) to improve pasture growth

(3) to boost reafforestation

(4) to allow a higher degree of food production

(5) to fight soil erosion

(6) to make best use of available water resources

(7) to suppress soil salinity and, in a few cases,

(8) to recharge groundwater.

However, there also some problems associated with water harvesting:

(1) a higher labour input than in rainfed farming

(2) higher difficulties due to unfamiliarity with the technology and/or an unreliable water supply

(3) a negative impact on soil and vegetation resources in the catchment area due to clearing or treatment

(4) a loss of individual control in large $\mathrm{WH}$ schemes and

(5) the possibility of increasing number of livestock which could cause more desertification.

In comparison to former times, farmers today have to produce in a very different social and economic environment. Nevertheless, the positive elements of WH remain valid and they can be used in future for the well-being of people in the dry areas of the world. Precondition is an adequate coverage of all technical, social, economic and environmental aspects of WH in planning and implementation (Prinz 1994) - as it was apparently the case in ancient times, when sustainability was reached for many centuries.

\section{CONCLUSIONS AND RECOMENDATIONS}

? The present social and economic frame conditions for farmers differ strongly from those in ancient times, when water harvesting was more common, whereas the natural conditions remained similar.

? The advantages of water harvesting remain valid and farmers in dry areas have to utilize them if they want to be able to master the future.

? Farmers need scientific and institutional support to start new projects.

? The failure of water harvesting projects in the past was sometimes due to technical failures but more often the attention given to social and economic aspects was insufficient.

? There should be a global cooperation between scientists and practitioners involved in water harvesting. By learning from failures and successes, a high degree of sustainability might be reached, similar to the one which apparently existed in the past and remained for a thousand or more years.

\section{REFERENCES}

1. Abdi, A. M. (1986). Water harvesting systems in the Northwestern region of Somalia. Paper presented to the World Bank Workshop on Water Harvesting in Sub-Saharan Africa, Baringo, Kenya, 13-17. Oct 1986. Baringo, Kenya.

2. Achouri, M. (1994). Small Scale Water Harvesting in Tunisia. In: FAO, Water Harvesting For Improved Agricultural Production. Expert Consultation, Cairo, Egypt 21-25 Nov. 1993, p. 87-97, FAO, Rome.

3. Adato, M. (1987). Runoff Agriculture for Arid and Semi-Arid Lands. Prospects based on Research at the Desert Runoff Farms in the Negev Desert of Israel. Desert Runoff Farms Unit. Bersheba, Israel. 
4. Al-Ghariani, S. A. (1994). Contour Ridge Terracing Water Harvesting Systems in North-West Libya. In: FAO, Water Harvesting For Improved Agricultural Production. Expert Consultation, Cairo, Egypt 21-25 Nov. 1993, p. 35-56, FAO, Rome.

5. Al-Labadi, M. (1994). Water Harvesting in Jordan- Existing and Potential Systems. In: FAO, Water Harvesting For Improved Agricultural Production. Expert Consultation, Cairo, Egypt 21-25 Nov. 1993, p. 221-231, FAO, Rome.

6. Antinori, P. and Vallerani, V. (1994). Experiments in Water Harvesting Technology with the Dolphin and Train Ploughs. In: FAO, Water Harvesting For Improved Agricultural Production. Expert Consultation, Cairo, Egypt 21-25 Nov. 1993, p. 113-132, FAO, Rome.

7. Arar, A. (1994). Optimization of Water Use in Arid Areas. In: FAO, Water Harvesting For Improved Agricultural Production. Expert Consultation, Cairo, Egypt 21-25 Nov. 1993, p. 287-301, FAO, Rome.

8. Bamatraf, A. (1994). Water Harvesting and Conservation Systems in Yemen. In: FAO, Water Harvesting For Improved Agricultural Production. Expert Consultation, Cairo, Egypt 21-25 Nov. 1993, p. 169-189, FAO, Rome.

9. Barrow, C. (1987). Water Resources and Agricultural Development in the Tropics. Longman, UK.

10. Ben-Asher, J. (1988). A Review of Water Harvesting in Israel. World Bank Working Paper 2. World Bank Sub-Saharan Water Harvesting Study, p. 47-69.

11. Boers, T. M. and Ben-Asher, J. (1982). A review of rainwater harvesting. Agric. Water Managem. 5:145-158.

12. Bruins, H. J., Evenari, M. and Nessler, U. (1986). Rainwater harvesting agriculture for food production in arid zones: The challenge of the African famine. Appl. Geogr. 6:13-33.

13. Brunner, U. and Haefner, H. (1986). The Successful Floodwater Farming System of the Sabeans, Yemen Arab Republic. Appl. Geogr. 6:77-89.

14. Burdass, W. J. (1975). Water harvesting for livestock in Western Australia. In: Proc. Water Harvesting Symp., Phoenix, AZ, ARS W-22, USDA, p. 8-26.

15. Buritz K. and Dudeck, E. (1986). Le project Agro-Ecologie. Philosophie et principes d'intervention après 4 ans d'experience. ORD du Yatenga/ORD du Sahel/DED, Burkina Faso.

16. Chrichley, W., Reij, C. and Seznec, A. (1992a). Water Harvesting for Plant Production. Vol 2. Case Studies and Conclusions from Sub-Saharan Africa. World Bank Techn. Paper 157.

17. Chrichley, W., Reij, C. and Turner, S. D. (1992b). Soil and Water Conservation in Sub-Saharan Africa: towards sustainable production by the rural poor. IFAD, Rome and CDCS, Amsterdam.

18. Cox, G. W. and Atkins, M. D. (1979). Agricultural Ecology: an Analysis of World Food Production. Freeman, San Fransisco.

19. Doolittle, W. E. (1984). Agricultural change as an incremental process. Annales Assoc. Americ. Geogr. 1:124-137.

20. Dutt, G. R., Hutchinson, C.F. and Garduno, M.A. (eds.) 1981. Rainfall Collection for Agriculture in Arid and Semi-arid Regions. Proc. of a workshop, University of Arizona and Chapingo Postgraduate College. Commonw. Agric. Bureaux, UK.

21. Eger, H. (1988). Runoff Agriculture. Reichert, Wiesbaden.

22. El-Amami, S. (1983). Les amenagements hydrauliques traditionels en Tunisie. Centre de Recherche du Genie Rural, Tunis, Tunisia.

23. El-Shafei, S. (1994). Agricultural Development in the North-West Coastal Zone, Egypt. Report on Water Harvesting. In: FAO, Water Harvesting For Improved Agricultural Production. Expert Consultation, Cairo, Egypt 21-25 Nov. 1993, FAO, Rome.

24. Evenari, M. and Koller, D. (1956). Ancient masters of the desert. Sci. Amer. 194(4):39-45.

25. Evenari, M., Shanan, L. and Tadmor, N. (1971). The Negev: The Challenge of a Desert. Harvard University Press Cambridge, MA., U.S.A.

26. FAO 1977. Soil Conservation and Management in Developing Countries. Soils Bull. 33. FAO, Rome.

27. FAO 1990. An International Action Programme On Water and Sustainable Agricultural Development. A Strategy for the Implementation of the Mar del Plata Action Plan for the 1990s. FAO, Rome. 
28. Finkel, H. J. and Finkel, M. (1986). Engineering Measures: Water Harvesting. In: Finkel H.J, M.Finkel and Z.Naveh, Semi-arid Soil and Water Conservation. CRC Press, Inc., Boca Raton, Florida: USA, p.93-101.

29. Frasier, G. W. and Myers, L. E. (1983). Handbook of Water Harvesting. Agric. Handbook 600. USDA, Washington DC.

30. Frasier, G. W. (1994). Water Harvesting/Runoff Farming Systems for Agricultural Production. In: FAO, Water Harvesting For Improved Agricultural Production. Expert Consultation, Cairo, Egypt 21-25 Nov. 1993, p. 57-73, FAO, Rome.

31. French, N. and Hussain, J. (1964). Water Spreading Manual. Range Management Re. 1, Pakistan Range Impr. Scheme. Lahore, Pakistan.

32. Gichangi, E. M., Jones, R. K., Njarui, D. M., Simpson, J. R., Mututho, J. M. N. and Kitheka, S. K. (1989). Pitting Practices for Rehabilitating Eroded Grazing Land on Smallholder Farms in the Semi-arid Tropics of Eastern Kenya - A Progress Report. Nat. Dryland Farming Res. Centre - Machakos, Kenya.

33. Gilbertson, D. D. (1986). Runoff (floodwater) farming and rural water supply in arid lands. In: Appl. Geogr. 6:5-11.

34. Huibers, F. P. (1985). Rainfed Agriculture in a Semi-Arid Tropical Climate: Aspects of Land and Water Management for Red Soils in India. Doctoral Thesis, Agric. Univ. Wageningen, NL.

35. Hurni, H. (1986). Soil Conservation in Ethiopia. Ministry of Agric., Addis Ababa, Ethiopia,

36. Ibrahim, H. (1994). Rainwater Harvesting in Dier-Atye (Syria). In: FAO, Water Harvesting For Improved Agricultural Production. Expert Consultation, Cairo, Egypt 21-25 Nov. 1993, p. 73-86, FAO, Rome.

37. Klemm, W. (1990). Bewässerung mit Niederschlagswasser ohne Zwischenspeicherung im Sahel. Dissert. Univ. Fridericiana Karlsruhe.

38. Kolarkar, A. S., Murthy, K. and Singh, N. (1983). Khadin-a method of harvesting water for agriculture in the Thar desert. Arid Environm. 6:59-66.

39. Kutsch, H. (1982). Principle Features of a Form of Water-concentrating Culture on Small-Holdings With Special Reference to the Anti-Atlas. Trierer Geogr. Studien 5. Trier.

40. Laing, I. A. F. (1981). Rainfall Collection in Australia. In: Dutt, G.R. et al. (eds.), Rainfall Collection for Agriculture in Arid and Semiarid Regions, p. 61-66. Commonwealth Agric. Bureaux, Slough, UK.

41. Lövenstein, H. (1994). From Water Harvesting to Crop Harvesting-Opportunities for the Efficient Use of Runoff Water by Crops. In: FAO, Water Harvesting For Improved Agricultural Production. Expert Consultation, Cairo, Egypt 21-25 Nov. 1993, p. 301-315, FAO, Rome.

42. MoALD (1984). Runoff Harvesting for Crops, Range and Tree Production in the BPSAAP-area. BPS AAP Interim Report, ch. 12: 78-113, Nairobi, Kenya.

43. Nabhan, G. P. and Sheridan, T. E. (1977). Living fencerows of the Rio San Miquel, Sonora, Mexico: traditional fence technology for floodplain management. Human Ecology 5:97-111.

44. Nabhan, G. P. (1984). Soil fertility renewal and water harvesting in Sonoran desert agriculture, the Papago example. Arid Lands Newsl. 20:21-38. Phoenix, USA.

45. Oosterbaan, R. J. (1983). Modern interferences in traditional water resources in Baluchistan. ILRI Annual Report 1982: p. 23-34. Wageningen, NL.

46. Oron, G., J. Ben-Asher, A. Issar and Th. M. Boers (1983). Economic evaluation of water harvesting in microcatchments. Water Resourc. Res. 19:1099-1105.

47. Oweis, T. and Taimeh, A. (1994). Overall Evaluation of On-Farm Water Harvesting Systems in the Arid Regions, In: Lacirignola, C. and A. Hamdy (eds). Proceedings, CIHEAM Conference "Land and Water Resources Management in the Mediterranean Region" 04. - 08. September, 1994, Valencano (Bari), Vol. III, p. 763-781

48. Oweis, T. and Prinz, D. (1994). Identification of Potential Water Harvesting Areas and Methods for the Arid Regions of West Asia and North Africa: Proposal for a Regional Research Project. In: FAO, Water Harvesting For Improved Agricultural Production. Expert Consultation, Cairo, Egypt 21-25 Nov. 1993, p. 401-412, FAO, Rome.

49. Pacey, A. and A. Cullis (1986). Rainwater Harvesting. The Collection of Rainfall and Runoff in Rural Areas. IT London. 
50. Papadopoulos, I. (1994). Water Harvesting from Greenhouses. In: FAO, Water Harvesting For Improved Agricultural Production. Expert Consultation, Cairo, Egypt 21-25 Nov. 1993, p. 97-101, FAO, Rome.

51. Prinz, D. (1986). Erhaltung und Verbesserung der landwirtschaftlichen Produktivität in den Tropen und Subtropen. In: Blanckenburg, P. and H.D. Cramer (eds.). Handbuch der Landwirtschaft und Ernährung in den Entwicklungsländern Bd 3., p. 115-168, Ulmer, Stuttgart.

52. Prinz, D. (1994). Water Harvesting and Sustainable Agriculture in Arid and Semi-arid Regions. In: Lacirignola, C. and A. Hamdy (eds). Proceedings, CIHEAM Conference "Land and Water Resources Management in the Mediterranean Region" 04. - 08. September, 1994, Valencano (Bari), Vol. III, p. 745-762.

53. Prinz, D., Tauer, W., Vögtle, Th. 1994. The Application of Geographic Information Systems to Identify Areas Suitable for Water Harvesting/Runoff Irrigation. Proceedings, XII CIGR World Congress, Milano 29.08 - 01.09.1994, Vol. I, p. 79 - 87.

54. Reij, C., P. Mulder and L. Begemann (1988). Water Harvesting for Plant Production. World Bank Techn. Paper. Washington DC.

55. Reijntjes, C., B. Haverkort and A. Waters-Bayer (1992). Farming for the Future. An Introduction to Low-External-Input and Sustainable Agriculture. The MacMillan Press, London.

56. Ryan, J. G., R. Sarin and M. Pereia (1980). Assessment of Prospective Soil-Water- and Crop Management Technologies for the Semi-arid Tropics of Peninsular India. ICRISAT, Patencheru, India.

57. Shatanawi, R. (1994). Water Harvesting in Jordan and the Region: Present Situation and Future Needs. In: FAO, Water Harvesting For Improved Agricultural Production. Expert Consultation, Cairo, Egypt 21-25 Nov. 1993, p. 391-401, FAO, Rome.

58. Shatta, A. and F. Attia (1994). Environmental Aspects of Water Harvesting. In: FAO, Water Harvesting For Improved Agricultural Production. Expert Consultation, Cairo, Egypt 21-25 Nov. 1993, p. 257-270, FAO, Rome.

59. Siegert, K. (1994). Introduction to Water Harvesting. Some Basic Principles for Planning, Design and Monitoring. In: FAO, Water Harvesting For Improved Agricultural Production. Expert Consultation, Cairo, Egypt 21-25 Nov. 1993, p. 9-23, FAO, Rome.

60. Somerhalter, T. (1987). Boden- und wasserkonservierende Maßnahmen im Oueddai, Tschad. DED, Berlin.

61. Tauer, W. and Prinz, D. (1992). Runoff Irrigation in the Sahel Region: Appropriateness and Essential Framework Conditions. In: Proceedings, Intern. Conference on Advances in Planning, Design and Management of Irrigation Systems as Related to Sustainable Land Use, Leuven, Belgium, 14-17 Sept. 1992, p. 945-953.

62. Tauer, W. and Humborg, G.(1992). Runoff Irrigation in the Sahel Zone: Remote Sensing and Geographic Information Systems for Determining Potential Sites. Markgraf, Weikersheim.

63. Tayaa, M. (1994). Present Situation and Prospects for Improvement of Water Harvesting Practices in Morocco. In: FAO, Water Harvesting For Improved Agricultural Production. Expert Consultation, Cairo, Egypt 21-25 Nov. 1993, p. 231-254, FAO, Rome.

64. Tobbi, B. (1994). Water Harvesting: Historic, Existing and Potentials in Tunisia. In: FAO, Water Harvesting For Improved Agricultural Production. Expert Consultation, Cairo, Egypt 21-25 Nov. 1993, p. 189-201, FAO, Rome.

65. UNEP (1983). Rain and Stormwater Harvesting in Rural Areas. Tycooly, Dublin.

66. Van Dijk, J. and C. Reij (1994). Indigenous Water Harvesting Techniques in Sub-Saharan Africa: Examples from Sudan and the West African Sahel. In: FAO, Water Harvesting For Improved Agricultural Production. Expert Consultation, Cairo, Egypt 21-25 Nov. 1993, p. 101-112, FAO, Rome.

67. Vijayalakshmi, K., K. P. R. Vittal and L. R. P. Singh (1982). Water Harvesting and Re-use. In: ICAR. A Decade of Dryland Agricultural Research in India 1971-1980, p. 103-119. New Delhi, India.

68. Vivian, G. (1974). Conservation and diversion water control system in the Anansazi Southwest. Anthropological Papers Univ. of Arizona, Tuczon-Arizona, USA, Vol. 25.

69. Von Oppen, M. (1985). Tank Irrigation in South India - Adapting a Traditional Technology to Modern Socio- economic Conditions. In: Traditional Irrigation Schemes and Potential for their Improvement. Irrigation Symposium 1985. DVWK Bull. 9, p. 109-118, Paul Parey, Hamburg/Berlin. 
70. Wildenhahn, E. (1985). Traditional Irrigation Systems in the Southwest of Saudi Arabia. In: Traditional Irrigation Schemes and Potential for their Improvement. Irrigation Symposium 1985. DVWK Bull. 9. p. 119-134, Paul Parey, Hamburg/Berlin.

71. Wright, P. (1985). Soil and Water Conservation by Farmers. OXFAM, Ouagadougou, Burkina Faso. 72. Zohar, Y., J.A. Aronson and H.Lövenstein (1987). Fuelwood and Fodder Crops in Rainfall Harvesting Systems Under Arid Conditions. A Research Progress Report, ARO Volcani Center. Bet Dagan, Israel.

SOURCE: Prinz, D., (1996). Water Harvesting: Past and Future. In: Pereira, L. S. (ed.), Sustainability of Irrigated Agriculture. Proceedings, NATO Advanced Research Workshop, Vimeiro, 21- 26.03.1994, Balkema, Rotterdam, 135-144 